\title{
An overview of interactions among oceanography, marine ecosystems, climatic and human disruptions along the eastern margins of the Pacific Ocean
}

\author{
Una visión general de las interacciones entre la oceanografía, los ecosistemas marinos y las \\ disrupciones climáticas y antrópicas en los márgenes este del Océano Pacífico
}

\author{
PATRICIA M. HALPIN ${ }^{1,2}$, P. TED STRUB ${ }^{3}$, WILLIAM T. PETERSON $^{4}$ \\ \& TIM R. BAUMGARTNER ${ }^{5}$ \\ ${ }^{1}$ Department of Zoology, Oregon State University, Corvallis, Oregon 97331, USA Current address \\ ${ }^{2}$ Marine Science Institute, University of California Santa Barbara, \\ Santa Barbara, California 93106, USA; e-mail: halpin@lifesci.ucsb.edu \\ ${ }^{3}$ College of Oceanic and Atmospheric Sciences, Oregon State University, Corvallis, Oregon 97331, USA \\ ${ }^{4}$ National Marine Fisheries Service, Northwest Fisheries Science Center, \\ 2030 South Marine Science Drive, Newport, Oregon 97365, USA \\ ${ }^{5}$ Centro de Investigación Científica y Educación Superior de Ensenada, División de Oceanología, \\ kilómetro 107, Carretera Tijuana-Ensenada, Ensenada, BC México
}

\begin{abstract}
Physical processes, biotic processes and human activities all act to shape marine ecosystems. Future management of these valuable ecosystems requires an integrative approach that takes into account complicated organismal interactions, oceanographic processes that span large scales of time and space, and how anthropogenic effects interact with the natural environment. The temperate west coasts of North and South America represent a unique opportunity for comparison, as many of the same oceanographic processes, particularly upwelling, occur off both coasts. Additionally, a number of marine ecosystems in both areas have surprising parallels. Here we present an overview of the oceanographic processes that dominate the coastlines, and give examples of ecosystems and the effects that oceanography, human activities and their interaction have on the communities.
\end{abstract}

Key words: eastern boundary currents, anthropogenic effects, marine community ecology, fisheries, interdecadal variability.

\section{RESUMEN}

Los procesos físicos y biológicos y las actividades humanas determinan los ecosistemas marinos. El manejo futuro de estos valiosos ecosistemas requiere de una aproximación integrativa que considere las complejas interacciones entre individuos, los procesos oceanográficos que se desarrollan a gran escala espacial y temporal, y la interacción de los efectos antropogénicos con el medio ambiente. Las costas templadas del oeste de Norteamérica y Sudamérica representan una oportunidad única para efectuar comparaciones ya que muchos procesos oceanográficos, particularmente la surgencia costera, ocurren en ambas costas. Adicionalmente, numerosos ecosistemas marinos en ambas áreas presentan sorprendentes paralelos. La presente revisión ofrece una visión general de los procesos oceanográficos dominantes en ambas costas y ofrece ejemplos de ecosistemas y los efectos que la oceanografía, las actividades humanas y las interacciones entre individuos tienen sobre las comunidades marinas.

Palabras clave: corriente de borde oriental, efectos antrópicos, ecología de comunidades marinas, pesquerías, variabilidad interdecadal.

\section{INTRODUCTION}

The western coastal regions off North and South America contain some of the most productive oceanic ecosystems in the world. In both hemispheres, many livelihoods depend on a variety of marine products derived from fish, invertebrates, and algae. These products contribute significantly to local and international economies, as well as local cultures. Considering only the fisheries, the combined annual landing of pelagic fish off Peru and Chile during good years ranges from 12-18 million metric tons (mmt), representing $15-20 \%$ of the global total of approximately $80-90 \mathrm{mmt}$. This directly adds $\$ 0.5$ to $\$ 1.0$ billion (USD) to the 
economies of each country. Indirect or induced impacts on their economies increase the benefit of these resources by a factor of 5-10 (FAO 1993, 1996). Although the catch from the United States west coast is much smaller (approximately $1 \mathrm{mmt}$ ), the United States Department of Commerce estimates its indirect impact on local economies as approximately $\$ 4.0$ billion USD (figures for 1991). Clearly, marine resources are important in both hemispheres.

The functioning of coastal ecosystems is inextricably linked to oceanographic processes that can vary across enormous spatial and temporal scales. Scientists are only beginning to appreciate how larger scale ocean basin processes influence community dynamics. Additionally, while the community dynamics of very nearshore benthic ecosystems have been actively researched, the dynamics of pelagic ecosystems are generally unknown apart from some basic food chain structures and broad responses to the physical environment. A poor understanding of how oceanographic processes interact with ocean ecosystems in conjunction with generally ill advised fishery practices has led to devastation of some fisheries. Recovery and management of fisheries along these coasts, as well as a deeper comprehension of how these ecosystems function, must take into account the oceanographic processes that underpin the biotic interactions.

Marine ecosystems must endure large-scale natural perturbations in addition to human induced disturbance. Important among these are El Niño and La Niña events (the two extremes of the El Niño Southern Oscillation (ENSO) "cycle"), tidal and current changes induced by the "Metonic" 18.6 year lunar cycle, the Pacific decadal oscillation (PDO), and long term climate change stemming from natural and anthropogenic sources (Fig. 1). All of these processes alter the physical conditions under which marine communities function, yet we have very incomplete information on their impacts. Management schemes that fail to take into account such cycles risk overexploiting populations during periods when natural environmental stresses are at a maximum, to the point where viable population size cannot be maintained in the face of other environmental stresses.

Here, we review the predominant oceanographic processes that characterize the western coasts of North and South America including a discussion of interannual and interdecadal variability, where known. Next we discuss rocky shores, kelp forests and pelagic fisheries as examples of how oceanic and oceanographic processes and human exploitation impact coastal marine ecosystems. We examine several examples of the interaction between marine resource use and the natural cycles of variability in populations. Although the exact details of these disruptions are still a matter of debate and ongoing research, their severe socioeconomic consequences are clear and unquestionable. We conclude with a discussion of the need to integrate oceanographic and ecologic perspectives and methodology, in order to better understand, preserve and use marine resources.

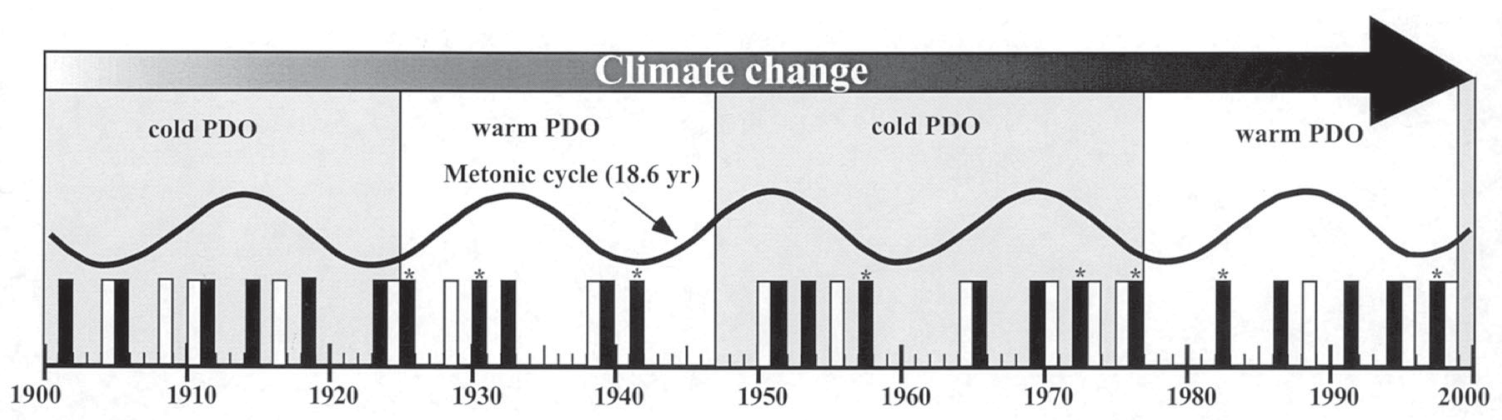

Fig. 1: Diagram of some important oceanographic cycles and events from 1900 to 2000. Dark bars indicate El Niño, severe events are marked with an asterisk; open bars indicate La Niña. Sine wave indicates the phase of the lunar 18.6 year Metonic cycle. Sections marked "warm" versus "cold" indicate shifts in the Pacific interdecadal oscillation. Arrow symbolizes long term global climate change and its recent acceleration due to anthropogenic sources.

Diagrama de algunos ciclos y eventos oceanográficos de importancia desde 1900 a 2000 . Las barras oscuras indican El Niño, los eventos severos se marcan con asteriscos; las barras claras indican eventos La Niña. Las ondas de seno indican la fase del ciclo Metónico lunar de 18.6 años. Las secciones marcadas "cálido" versus "frío" indican cambios en la oscilación Pacífica interdecadal. Las flechas simbolizan el cambio climático Global de largo plazo y su reciente aceleración debido a fuentes antropogénicas. 


\section{OCEANOGRAPHY}

\section{Background: description of the systems}

Along the western coasts of North and South America the climate and environment is dominated by the California and the Peru-Chile currents, respectively, which form wide, meandering near-surface flows directed toward the equator (recent reviews of the California and Peru-Chile current systems are presented in Hickey (1989) and Strub et al. (1998)). At the surface, these two eastern boundary currents (EBCs) transport cooler, fresher, nutrient-rich waters toward the warmer, saltier and nutrientdepleted waters of the tropics. Poleward undercurrents occur in both systems, transporting warm, salty, oxygen-poor and nutrient-rich water to higher latitudes. The large scale dynamics of coastal waters, driven by coupling between the ocean and the atmosphere over the Pacific basin, determine regional and local dynamics of these currents. Upwelling of colder, nutrient-rich water, a fundamental process within these currents, drives the high productivity of nearby coastal ecosystems. Upwelling occurs at the coast and also in the offshore regions of the currents (within several hundred kilometers of the coast), driven by winds and the internal dynamics of meanders and eddies within the currents. In turn, upwelling affects the largescale winds through the interplay among the ocean surface temperature, land surface temperature, and the overlying atmospheric wind and pressure systems. These eastern boundary currents thus play a significant role in controlling the large-scale climatic conditions that affect both the oceans and the continents of North and South America. Because of their productivity, they contribute a significant portion of the world's supply of protein and other marine products, through the harvest of their living marine resources.

The basin-scale circulation features that impact EBCs include equatorial current systems at low latitudes, west wind drift currents at mid to high latitudes and deep ocean eddies along the offshore edge of the systems at mid latitudes. In the California current, the seasonal EBC itself is believed to create these eddies (Strub \& James 2000) which may help to retain zooplankton and fish larvae near the coast. Much of the variability in the Peru-Chile current system, may be derived from coastally trapped waves with an equatorial origin.

In all EBCs a poleward undercurrent moves over the continental slope (Neshyba et al.
1989). Direct measurements of the poleward undercurrent off North America show that it flows continuously from southern California $\left(33^{\circ} \mathrm{N}\right)$ to the British Columbia coast $\left(51^{\circ} \mathrm{N}\right)$ (Pierce et al. 2000). The undercurrent off South America has been traced using water mass characteristics from off Peru $\left(5^{\circ} \mathrm{S}\right)$ to southern Chile (48 S) (Silva \& Neshyba 1979).

The undercurrent potentially performs several roles in population regulation. It is often considered the source of the nutrients drawn to the surface by upwelling, providing the basis for new production. Zooplankton and fish larvae can also use the poleward flow to maintain their latitudinal positions in an otherwise equatorward surface flow via vertical migration (Peterson 1998). In contrast, the poleward undercurrent off Peru and Chile transports water with extremely low concentrations of oxygen which may harm marine life when brought to the surface next to the coast during strong upwelling events.

The physical environment and coastal ecosystems in the Pacific EBCs respond strongly to climatic changes on a variety of scales. Responses to the basin-scale ENSO fluctuations are well documented (Chelton 1982, Barber \& Chavez 1983, Wooster \& Fluharty 1985, Castilla et al. 1993, Lubchenco et al. 1993). Recently, evidence for the sensitivity of these systems to interdecadal variability, with time scales of 5060 years, has become equally convincing. This is particularly clear for the north Pacific basin, where the well observed basin-wide climatic shift in the mid-1970s resulted in reorganization of heat storage in the ocean (Hahn \& Denny 1989, Miller et al. 1994, Miller 1996), in the circulation in the atmosphere, and the subsequent wind-driven circulation in the surface ocean affecting the oceanic ecosystems at trophic levels from phytoplankton to salmon (Polovina et al. 1995, Brodeur et al. 1996, Mantua et al. 1997). The eastern Pacific margin experienced a warming that stretched along the coast from southern California into the Gulf of Alaska, with a concurrent cooling in the central north Pacific. Graham's (1994) analysis suggests that this decadal scale change originated in the tropics and reached the North Pacific through atmospheric interconnections. Similarities between the surface temperature and atmospheric pressure patterns associated with ENSO and with interdecadal variability in the North Pacific have been noted by several studies (Graham 1994, Mantua et al. 1997, Enfield \& Mestas-Nunez 1999).

Both of these EBC systems are forced by a combination of "local" winds and basin-scale 
currents. By "local" winds, we mean the largescale wind fields directly over the EBCs, noting that currents at a given location are actually forced by wind stress at locations $300-500 \mathrm{~km}$ away in the equatorward direction (Gill \& Clarke 1974, Denbo \& Allen 1987). At midlatitudes, these winds result from offshore highpressure systems found over the eastern sides of the ocean basins that drive equatorward, upwelling-favorable winds along the coast. In spring and summer, the high pressure systems are larger and stronger and often interact with "thermal" low-pressure systems over the continents to create a seasonal intensification and expansion of the equatorward wind regime. At lower latitudes, the trade wind system associated with the seasonally migrating intertropical convergence zone (ITCZ) is more important in the northern Peru-Chile current, creating an austral winter maximum in upwelling off Peru. At higher latitudes, storms drive poleward (downwelling-favorable) winds that peak in winter in each hemisphere.

The 18.6 year lunar cycle or Metonic cycle, has been scrutinized as a long period oceanographic cycle that may be biologically relevant (Royer 1993, Beamish 1995). The Metonic cycle is driven by the change in the angle of the lunar orbit with the plane of the earth's rotation about the sun. The result is an 18.6 year cycle affecting tidal currents. During times of low declination, the difference between extreme, "spring," high and low tides is greater and the difference between neap tides is less (Denny \& Paine 1998). While the magnitude and effects of the lunar cycle remain unclear and controversial, the cycle has been implicated as an influence on a number of climactic (Maksimov \& Smirnov 1967, Loder \& Garrett 1978, Currie 1993) and biotic (Currie 1991, 1992, Beamish 1995) variables. Particularly controversial is the interaction of tropical systems with the lunar cycle. Tropical atmospheric mechanisms such as the Southern Oscillation seem to drive much of the global atmospheric and oceanic variation, but lunar influences may most strongly affect higher latitudes (Ware 1995). The extent to which celestial phenomena influence long-period oceanographic events and how these mechanisms interact with each other remain to be investigated.

\section{Northeast Pacific: the California current system}

The California current system is the most thoroughly studied of the EBCs (Hickey 1979,
Chelton 1981, Chelton et al. 1982, Lynn \& Simpson 1987, Hickey 1989, 1998, Strub \& James 2000). There are still questions, however, about even the large-scale circulation patterns (Brink \& Cowles 1991, Strub et al. 1991).

The mid-summer circulation of the EBC off the coast of western North America often consists of a convoluted, meandering, equatorward jet that flows from the Canadian border to the southern California bight (Fig. 2, Lynn \& Simpson 1987, Strub \& James 1995, Strub \& James 2000). The equatorward jet first appears in spring, offshore of cold water that often forms cyclonic vortices in satellite SST images. These colder patches of upwelled water appear to be separately created at the prominent capes off northern California in the spring (April-May), joining later to form a scalloped band all along the coast (Fig. 2A). The manner in which the system evolves from isolated upwelling centers to a continuous band is poorly understood. By June, the scalloped band extends northward to central Oregon and becomes a very narrow band next to the coast (Fig. 2B), consistent with the narrow (10-40 $\mathrm{km}$ ) spring-summer upwelling system off Oregon and Washington documented in the 1970's. By July, the band becomes continuous as far north as Canada, separating from the coast near Cape Blanco, $43^{\circ} \mathrm{N}$ (Barth \& Smith 1998, Barth et al. 2000), before meandering hundreds of kilometers offshore of California.

In boreal fall and winter the jet continues moving offshore, losing its continuity as poleward flow (the Davidson current) replaces the equatorward current next to the coast (Fig. $2 \mathrm{~A}$ and $2 \mathrm{D}$ ). In winter the jet leaves an offshore eddy field that dissipates partially by spring, when the cycle begins again. Eddies from the previous year are still present offshore when the jet moves into that region in mid-summer, providing some interaction between the ambient eddy field and the evolving jet.

The seasonal jet also transports nutrients and biological materials far offshore. Strub et al. (1990) used satellite color (CZCS) data to show that the surface pigment field moves offshore in fall and winter with the jet and eddy field, leaving a wide region of moderately high chlorophyll concentrations. Whether offshore phytoplankton populations are primarily consumed by higher trophic levels or simply add carbon to ocean sediments remains an open question (Thomas et al. 1994).

The southern California bight creates a break in the California current, caused by the change in coastal orientation. Winds and upwelling weaken in the bight, where a 

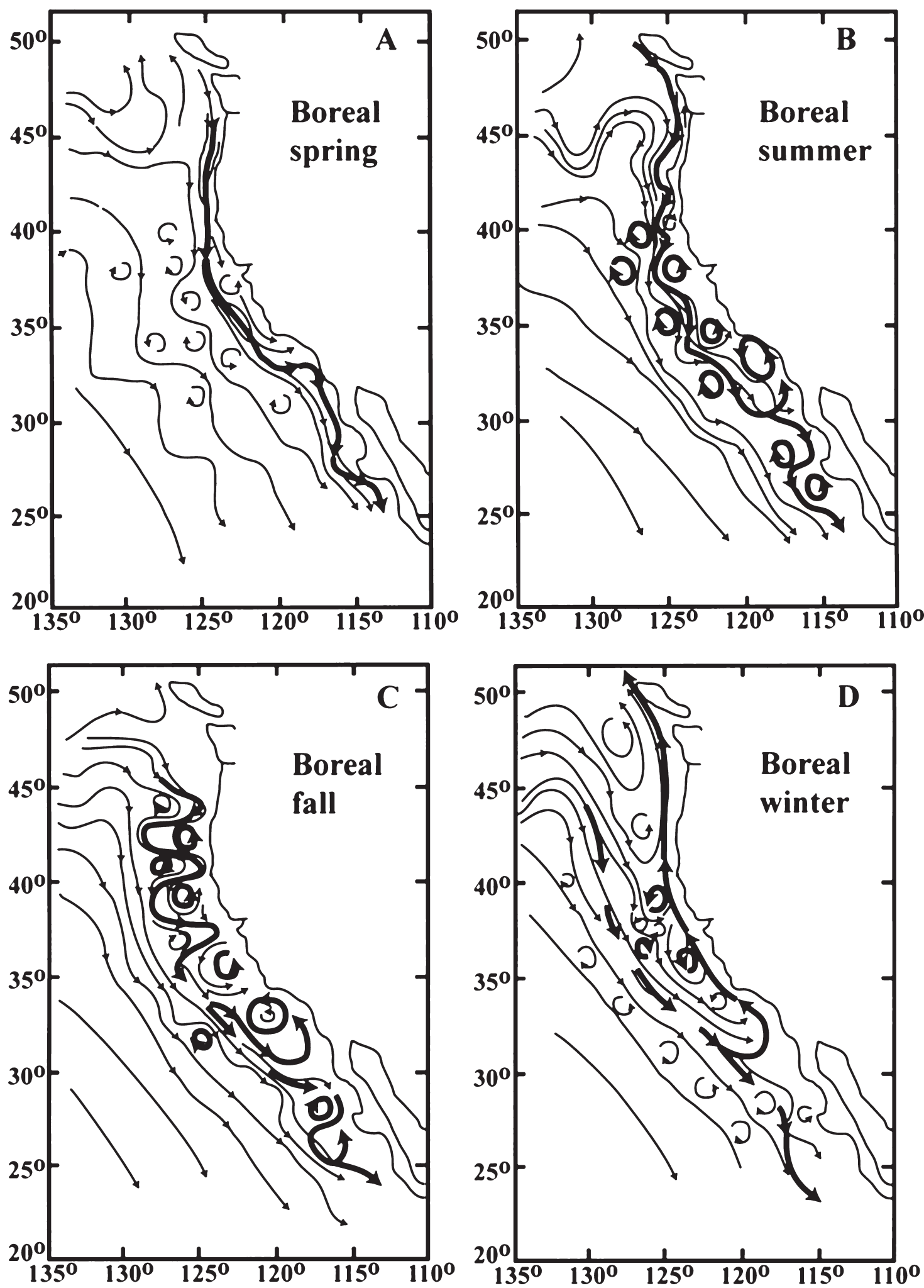

Fig. 2: A conceptual diagram of the seasonal evolution of the circulation in the California current system (after Strub \& James 2000).

Diagrama conceptual de la evolución estacional de la circulación en el sistema de la corriente de California (en base a Strub \& James 2000). 
cyclonic (counter-clockwise) circulation forms in summer. This cyclonic gyre, coupled with strong stratification and calm winds, creates a retention center that favors larval fish survival and is used as a "nursery" area for many species of fish. Off Baja California, upwelling favorable winds blow for the entire year, although weaker than summer winds off central and northern California. The California current turns offshore between $10-20^{\circ} \mathrm{N}$, into the westward North Equatorial current (NEC). Flow along Central America is poleward in the Costa Rica current and at a maximum in summer.

Although several mechanisms contribute to interannual variability in the California current system, much of the variability is related to the ENSO cycle in the equatorial Pacific. El Niño affects the basin circulation directly through propagation along the equatorial and coastal wave guides, followed by Rossby wave propagation away from the coasts. This is often called the "oceanic pathway" of ENSO effects on the Northeast Pacific circulation. The ENSO cycle also affects the mid latitude oceans indirectly through changes in strength and position of the mid and high latitude atmospheric pressure systems and the winds they drive directly over the California current. This is often called the "atmospheric pathway" for ENSO effects.

Variation in the strength of the California current affects the biota off western North America. A series of analyses of the first 30 years of California Cooperative Oceanic Fisheries Investigations (CalCOFI) data (19501980) found that zooplankton biomass in the southern California current system was positively correlated with the strength of the equatorward transport. Periods of reduced transport, and so reduced zooplankton biomass, were primarily coincident with warm phases of the ENSO cycle (El Niño) in the eastern Equatorial Pacific (Chelton 1981, Chelton et al. 1982). Advection of nutrients from the Alaskan gyre via the California current may allow increased primary productivity, which in turn supports the increased zooplankton biomass observed during periods of stronger flow (Wickett 1967). This hypothesis stemmed initially from observations that the water was often cooler and fresher than locally upwelled water during periods of greater equatorward advection during the cool phase of the ENSO cycle, the La Niña periods.

Changes in the strength of the transport in the California current were hypothesized to be related to changes in the position of the west wind drift. Chelton \& Davis (1982) used tide gauge sea level height data to show that variations in sea level and in alongshore coastal currents covaried in phase from southern California around the Gulf of Alaska. Since the currents in the eastern margin of the Alaska gyre and California current flow in opposite directions, the strengths of the boundary currents in the two gyres were hypothesized to covary out of phase, with the poleward flow of the Alaska gyre exhibiting increased flow when the equatorward California current exhibited decreased flow. Years with reduced equatorward/increased poleward flow corresponded to warm phases of the ENSO cycle. Chelton \& Davis (1982) hypothesized that this relation was due to interannual shifts in the position of the west wind drift, which feeds both boundary currents, increasing the flow into one or the other of these systems in a given year (Fig. 3). Thus, hypothetically, changes in the flow, water mass characteristics and zooplankton biomass in the California current depends on variability in the position of the west wind drift, with a connection to the inter-annual ENSO cycle through atmospheric forcing.

An alternate source of the cooler, fresher water found in some years off southern California is the seasonal jet (Fig. 2) connecting the flow along the coasts of Oregon, Washington, and British Columbia (Strub et al. 1991, Smith 1992, Strub \& James 1995, Strub \& James 2000, 2002a, 2002b). Upwelled water in the coastal region of the Pacific Northwest is cold, rich in nutrients, and fresher than water off southern California, due to discharges out of the Columbia River, the Juan de Fuca Straights and the Gulf of Alaska coast. Altimeter and drifter data show a direct connection between the coastal ocean off British Columbia and the Pacific Northwest, providing an even fresher source of water at the northern end of the seasonal jet shown in Fig. 2. The jet moves offshore around $42^{\circ} \mathrm{N}$ (Barth $\&$ Smith 1998, Barth et al. 2000) and feeds directly into the core of the California current, while drifters released in the west wind drift generally stay offshore of the core of the current (Mcnalley 1981). Thus the source of the anomalous water noted by Chelton et al. (1982) and others may be local to the boundary currents, upstream of the observations, with little connection to the west wind drift. Interannual variability in the seasonal jet is affected by winds over the California current, which again are linked to interannual ENSO variability. 

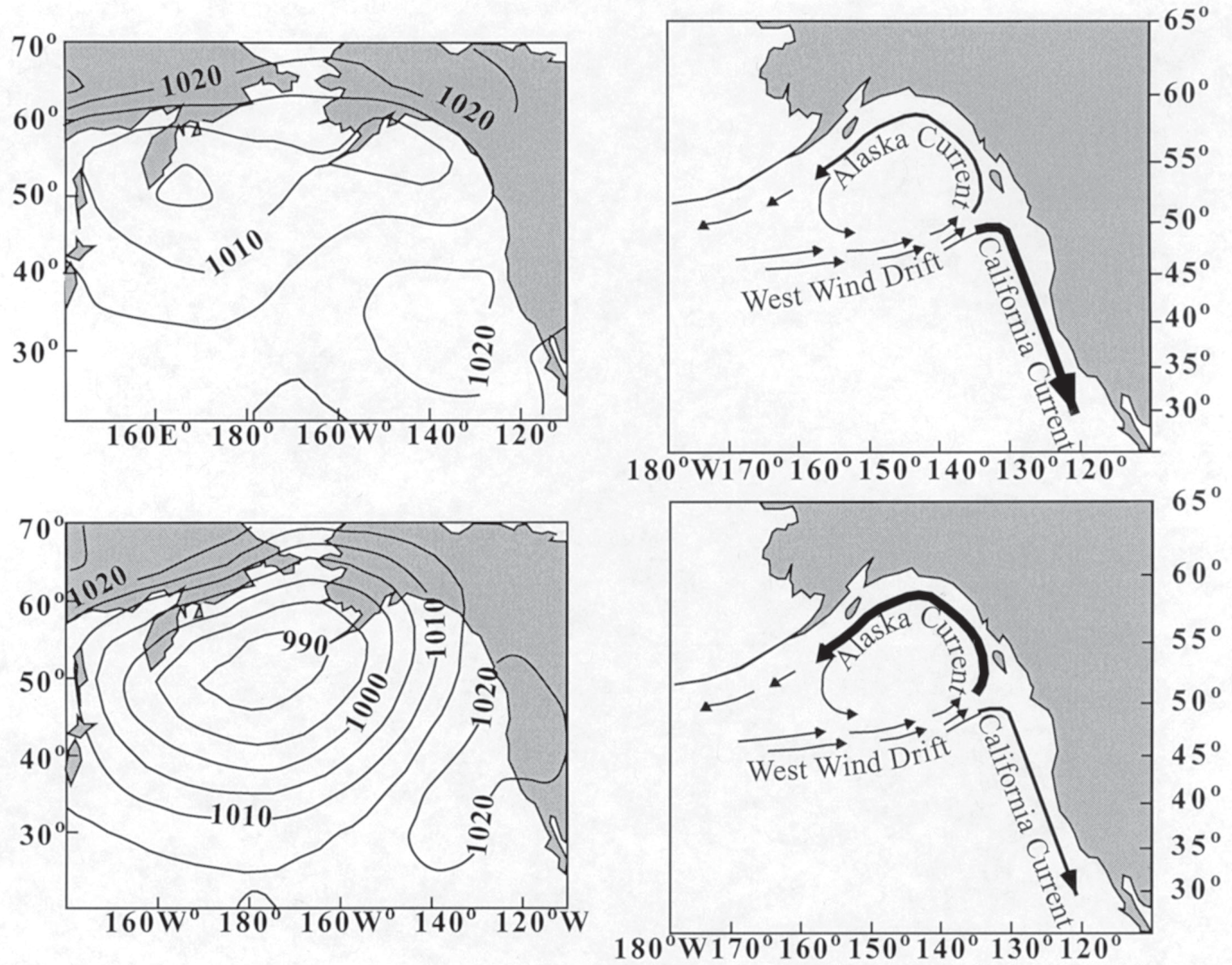

Fig. 3: Winter mean sea level pressure. Alternate states of oceanic circulation patterns in the North Pacific Ocean (after Emery \& Hamilton 1985, Hollowed \& Wooster 1992, de Brodeur et al. 1996).

Promedio de invierno de la presión a nivel del mar. Estados alternativos de los patrones de circulación oceánica en el norte del Océano Pacifico (en base a Emery \& Hamilton 1985, Hollowed \& Wooster 1992, de Brodeur et al. 1996).

A third source of interannual variability in the California current is the wind-driven onshore Ekman flow at the surface. During some El Niño years, boreal winter storm activity strengthens along the coast, driving more water onshore from the deep ocean, raising sea levels, deepening the mixed layer and warming the surface temperatures of the California current (Simpson 1984). A fourth source of variation potentially arises from the direct connection between the California current, the equatorial ocean, and the ENSO cycle via the coastal waveguide along the margins of the Pacific, the oceanic pathway (Chelton \& Davis 1982). Tide gauge data clearly shows the propagation of interannual variability in sea level from the equator to the California current and beyond (Enfield \& Allen 1980, Chelton \& Davis 1982). Pares-Siera \& O'Brien (1989) demonstrate through a numerical model that much of the interannual variability in the flow in the California current propagates into the region along the coast from the south, with an equatorial source linked to the ENSO cycle.

The difficulty in determining the relative strengths of these four processes in creating the observed interannual variability in the California current lies in their correlation with the ENSO variability. This creates difficulties in separating their importance using linear statistical analyses. During the 1997-1998 El Niño, however, altimeter data, wind fields and in situ measurements clearly document the temporal development of surface circulation variability during one strong event.

Two periods of high sea level occurred at the equator, one in May-July 1997 and the other in October-January 1997-1998. High sea levels and poleward surface transports quickly 
propagated south (poleward) along the coast of South America in May-June 1997, aided by poleward winds during austral fall. The same signals propagated north along the coast of Central America, but stalled near the mouth of the Gulf of California. During July, the first signal of raised sea levels appeared in the southern Gulf of California, then moved slowly up Baja California, opposed by equatorial winds during boreal summer. During the second period of equatorial high sea levels, the winds reversed off North America, becoming poleward (north) during boreal fall and winter. Subsequently, high sea levels and poleward transports propagated quickly off the coast of North America and around the Gulf of Alaska in October and November 1997. Thus, these signals had an equatorial origin but were also aided by local winds. As to connections to the west wind drift, the poleward boundary currents intensified in fall, followed by an intensification of the entire Alaska gyre including the northern half of the west wind drift. This produced a circulation anomaly somewhat similar to that proposed by Chelton \& Davis (1982). The sequence of events makes it clear, however, that the strengthened northern half of the west wind drift is a result of the basin scale wind forcing and follows the changes in the boundary currents, rather than driving them (Strub \& James 2002b).

The movement of the west wind drift has also been put forward as a possible mechanism for creating the interdecadal changes in the boundary currents. Fig. 3 shows the general pattern of hypothesized changes in atmospheric forcing (a stronger or weaker Aleutian low pressure system) and oceanic response (more flow into the California current or coastal Alaska current) conjectured to be responsible for interdecadal changes in zooplankton and fish abundance (Hollowed \& Wooster 1992, Brodeur et al. 1996). This mechanism for interdecadal change also remains a topic of ongoing research, using both historical data in retrospective studies and coupled atmosphereocean models to investigate the dynamics (United State GLOBEC 1996).

On smaller scales in nearshore ecosystems, an unknown but potentially important component driving nearshore ecosystem differences is variability at the "mesoscale" (i.e., tens to hundreds of kilometers). Menge et al. (1996, 1997a, 1997b) demonstrated that chlorophyll "a" (Chl-a) concentrations differ consistently between onshore sites along the Oregon coast. Sampling at spatial scales of 1$100 \mathrm{~km}$, and temporal scales of hours to weeks, they established that the $10-100 \mathrm{~km}$ scale was the most useful at explaining variability in Chla concentrations. Temporally, daily sampling was sufficient to capture changes in water quality. Onshore Chl-a concentrations peak after upwelling events when phytoplankton concentrated at the upwelling front drift toward shore. Benthic diatoms may bloom in response to upwelling and contribute to measured Chl-a levels. Study sites spaced $50+\mathrm{km}$ apart consistently exhibited different concentrations when sampled from shore. Several years of data indicate that either phytoplankton are delivered onshore in different concentrations or the condition for phytoplankton production at the offshore upwelling front varies along the coast in a predictable fashion. In addition to Chl-a, recruitment of mussels varies along the coast in a similar, predictable fashion, providing further evidence of biologically important oceanographic processes at work. The exact oceanographic mechanism of these onshore mesoscale differences remains to be elucidated. The biological ramifications of these conditions are discussed in more detail below.

\section{Southeast Pacific: the Peru-Chile current system and its Equatorial connection}

The Peru-Chile current system has not been studied in as much detail as the California current, especially off Chile (Strub et al. 1998). This system has the greatest latitudinal extent of any EBC, stretching from the equator to $55^{\circ}$ $\mathrm{S}$ (Fig. 4). The equatorward-flowing portion of the current, however, only extends as far south as approximately $42-45^{\circ} \mathrm{S}$ in austral summer and $32-35^{\circ} \mathrm{S}$ in winter. South of $40-45^{\circ} \mathrm{S}$, the poleward Cape Horn current is found, driven by poleward, downwelling-favorable winds and strong buoyancy forcing by heavy precipitation, similar to the coastal regions of the northeast Pacific along British Columbia and Alaska.

The continuous equatorward current that connects the regions of Chile and Peru to the westward south Equatorial current differs from the flow in the California current, which turns westward far north of the equator. The direct connection between the equatorial current systems and the Peru-Chile current provides its most unique aspect-a prevalence of poleward flow that affects it from $5^{\circ} \mathrm{S}$ to $35^{\circ} \mathrm{S}$ or farther south. This is especially important during El Niño, when higher sea levels and warmer coastal temperatures are found from north of the equator to approximately $33-36^{\circ} \mathrm{S}$. The connection also influences normal periods, 


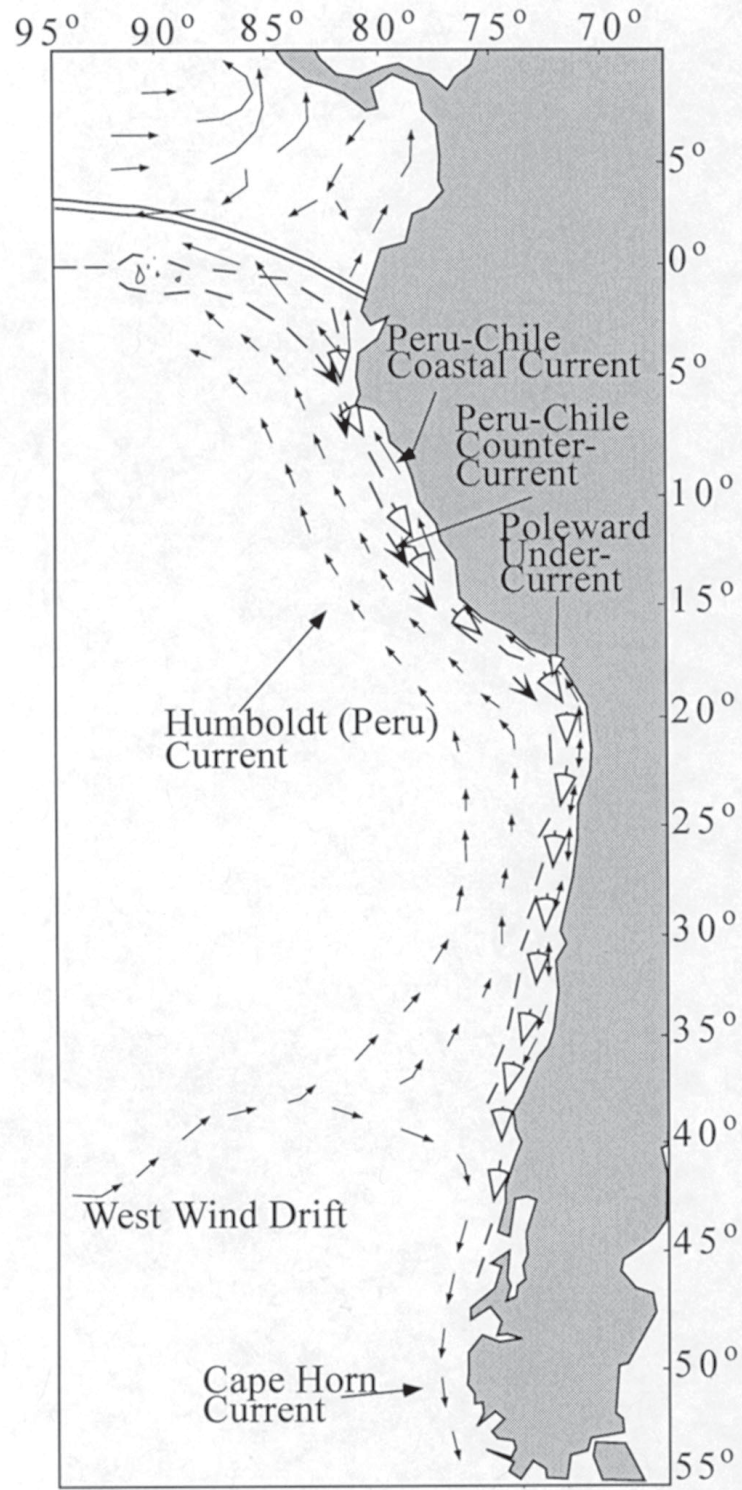

Austral winter

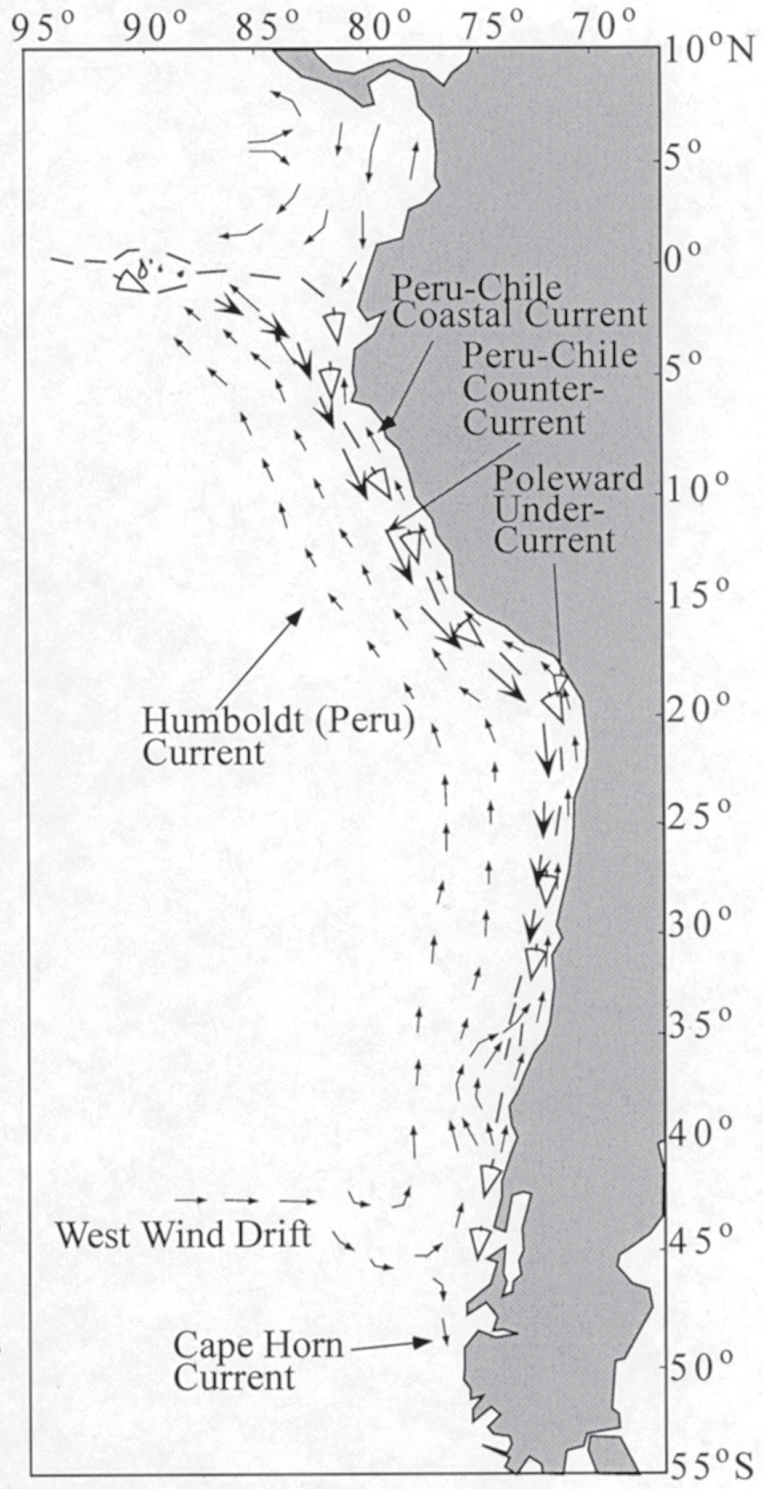

Austral summer

Fig. 4: Currents during austral winter and summer. Schematic vectors are drawn to indicate the location and relative strengths of the currents (after Strub et al. 1998).

Corrientes durante el invierno y verano austral. Los vectores esquemáticos se dibujan para indicar la localización e intensidad relativa de las corrientes (en base a Strub et al. 1998).

when strong poleward flows occur under the shallow, wind driven, equatorward current and also in an offshore poleward countercurrent, described in more detail below.

The low-latitude upwelling region off Peru received intense study between 1976-1985 (Brink et al. 1981, Brink et al. 1983 and references in the same volume). This region has no true counterpart in the other eastern boundary currents, although the currents off Northwest Africa between $10-20^{\circ} \mathrm{N}$ show some similarities in seasonality. Equatorward winds are strongest in austral winter (JulySeptember), when the ITCZ is farthest north and the southeast trade winds are well established. At this time, the equatorial cold tongue connects the coastal upwelling region off Peru to the equatorial upwelling region west of the Galapagos Islands, creating the strong equatorial front north of the cold tongue. These winds relax in austral spring and summer (October-March) as the ITCZ moves toward the 
equator, allowing the cold tongue to collapse and a warm tongue to develop that reaches from the equator to central Chile, offshore of the narrow upwelling region (Strub \& James 1995). At the same time (austral springsummer), equatorward winds intensify off central Chile and upwelling occurs in episodes with time scales of 7-10 days. Upwelling is most intense at upwelling centers near small capes and bays, where filaments of cold water expand offshore and then retreat as the wind pulses. The offshore size of these filaments is less than in the California current: $25-50 \mathrm{~km}$ off Peru (Brink et al. 1981) and 60-125 km off Chile (Fonseca \& Farias 1987).

The region most equivalent to the large, seasonal, meandering jet in the California current system occurs between approximately $35-44^{\circ} \mathrm{S}$, remaining closer to the coast than off California. Surface salinities from a summer cruise in 1960 (Brandhorst 1971) indicate a large plume of less saline water extending offshore around $42-44^{\circ} \mathrm{S}$, arcing back onshore near $35^{\circ} \mathrm{S}$. Inshore of this fresh plume is a region of higher salinities next to the coast between $38-35^{\circ} \mathrm{S}$, indicating the area of upwelling and offshore Ekman transport. A separate tongue of salty water flows from the north to around $33-35^{\circ} \mathrm{S}$. This may be the southern end of the Peru-Chile countercurrent. The arcing summer flow can be seen in Geosat altimeter height fields (Strub et al. 1998), appearing much smaller than that found off California. The strongest and most continuous feature in the altimeter fields, however, is not the expected equatorward flow, but the poleward offshore countercurrent. Both gridded heights from Geosat and crosstrack geostrophic currents from the Geosat and TOPEX/ POSEIDON altimeters show a band of poleward current, $100-300 \mathrm{~km}$ offshore, that reaches from $6-8^{\circ} \mathrm{S}$ to $35^{\circ} \mathrm{S}$ (or farther), maximum in spring and minimum (or reversed) in fall (Strub et al. 1995). This offshore PeruChile countercurrent (Fig. 4) is hypothesized to connect to the Equatorial undercurrent(Tsuchiya 1985, Lukas 1986). It is also evident between 100-300 $\mathrm{km}$ offshore in the hydrographic surveys of Huyer et al. (1991) off Peru. Off Chile, Fonseca (1989) refers to a band of poleward currents between 100-200 km offshore as one of the features found most consistently in repeated hydrographic surveys. Thus, although the altimeter cannot determine absolute velocities, Strub et al. (1995) hypothesize the countercurrent to be present much of the year and maximum in austral spring.
The large "bight" off southern Peru and northern Chile (where the coastline changes orientation) may be the analog to the southern California bight. A recent climatology for the region between $18-24^{\circ} \mathrm{S}$ (Blanco et al. 2001) shows that winds are weaker than in the surrounding regions; the circulation is weak; there is an anticyclonic gyre in summer; and stratification is strong in the upper water column. The weak, possibly recirculating, flow would provide the mechanical means for retention of larval fish, as in the southern California bight. The large distribution of small pelagic fish off northern Chile suggests that the pelagic ecosystems of the two areas may be similar.

The narrowness of the South American upwelling system is supported by the climatology of satellite and in situ SST and by satellite estimates of surface pigment concentrations (Thomas et al. 1994). Although sampling and algorithm problems may affect the absolute values of satellite-derived surface pigment concentrations in the Peru-Chile system, the spatial patterns are consistent with other evidence that implies a much narrower upwelling system and a summer jet that stays within $200 \mathrm{~km}$ of the coast between $35-45^{\circ} \mathrm{S}$. Upwelling-favorable wind forcing is also weaker off Chile than off California. Thus, some of the major unanswered questions about the circulation concern the relation between the various physical components of this system: the offshore countercurrent, the wind forcing, the width and alongshore extent of the upwelling system.

Much of the interannual variability of this system is driven directly by the ENSO cycle, especially north of $35^{\circ} \mathrm{S}$ (Enfield et al. 1987, and references in the same volume). Fonseca (1985) found a strong El Niño signal in 19821983 coastal SSTs to extend to $35^{\circ} \mathrm{S}$ but not farther. Coastal tide gauges show the El Niño signal to propagate to at least $35^{\circ} \mathrm{S}$ (Blanco et al. 2002). High sea levels and poleward currents found south of $35^{\circ} \mathrm{S}$ are likely to be influenced by winds associated with ENSO effects (as in the northern hemisphere), but this has not been systematically explored. Likewise, changes in the variability caused by changes in the west wind drift are a possibility that has not been investigated. However, several recent studies have identified coastal-trapped waves with periods of approximately 50 days off northern Chile (Shaffer et al. 1997). These waves arise equatorially and are hypothesized to biologically important due to their modulation of coastal upwelling. Their effects 
are currently under investigation. The availability of new satellite ocean sensors and the increased sea-going capabilities of the Chilean oceanographic community should clarify many of these issues over the next decade. Likewise, the presence of interdecadal variability in ocean conditions and fish populations has yet to be addressed in the Southeast Pacific ocean. Inter- decadal variability in fish catch is well documented, but is confounded by changes in effort to catch different species.

Recent data sets from Chile demonstrate nearshore variation in phytoplankton concentrations at the scale of 15-20 km. Despite large temporal variation, spatial variation in concentrations appears dependent on position relative to upwelling regions created by local geography. Water at the upwelling center site was colder with lower phytoplankton concentration (Wieters et al. 2003).

Major unanswered questions remain about marine productivity in North and South America. Even when the Peruvian fishery is excluded (there is no equivalent region off North America), the Chilean total fish catch is larger (approximately $6 \mathrm{mmt}$ ) than that off western North America (approx. 1-2 mmt). In the past several years (prior to the 1997-1998 El Niño), northern Chile has averaged $2 \mathrm{mmt}$ of anchovy harvests, implying a much larger standing stock than traditionally found off North America. Is this because of a greater level of primary productivity, higher rates of larval survival in the larger "bight," or other factors? Initial estimates of phytoplankton concentrations from the CZCS satellite color sensor indicated much lower levels of pigment concentrations off northern Chile than off California (Thomas et al. 1994). A great deal of work remains to be done to understand the differences between these pelagic ecosystems.

\section{EXAMPLES OF MARINE ECOSYSTEMS AND THEIR INTERACTIONS WITH HUMAN AND OCEANOGRAPHIC IMPACTS}

\section{Rocky intertidal ecosystems: common features}

Exposed rocky shores in the temperate regions of both North and South America contain extensive and actively researched benthic ecosystems, due to their accessibility and the low mobility of the organisms that make up the community. Intertidal communities are generally space limited with invertebrate filter feeders and macroalgae forming the primary cover. Barnacles and algae typically occupy the highest intertidal areas, followed by mussels in the mid-intertidal zone, and a combination of invertebrates and macroalgae in low to subtidal areas. However, the distribution and abundance of primary cover changes with biotic and abiotic conditions of the area.

Both macroalgae and invertebrate primary space occupiers, usually barnacles or mussels, can be considered basal trophic species in these ecosystems, though filter feeders are not autotrophs (Menge et al. 1999). Since filter feeders consume plankton and dissolved organic matter within the water column, they, like algae, transfer carbon from outside sources to within the community. In many intertidal areas they may be the principal agents of this transfer. Also, as dominant space occupiers, benthic filter feeders provide the basic spatial structure of the community in much the same fashion as terrestrial trees and subtidal giant kelps (Lohse 1993). Therefore, the productivity and biomass of rocky intertidal communities depend in part on the properties of the water flowing over both algae and invertebrates at high tide, though the measure of water quality will be different for each group.

Generally, the animals in the upper trophic levels exerting the strongest community effects are invertebrates such as seastars and muricid gastropods (Paine 1966, 1974, 1976, Moreno et al. 1986, Castilla \& Paine 1987). While birds and fish can alter the population structure of their prey, they have not been demonstrated to influence community structure to the degree that invertebrate predators do (but see Frank 1982, Hahn \& Denny 1989, Wootton 1997). The Chilean clingfish or pejesapo, Sicyases sanguinus, may be an exception to this (Paine \& Palmer 1978, Cancino \& Castilla 1988). Pejesapos consume algae and sessile invertebrates off rocks via scraping, and use specialized pelvic fins that function as suction cups to remain in extremely exposed, wave-swept environments. Whether the Chilean clingfish can function as a keystone predator remains unknown, as the fish inhabit vertical walls in extremely turbulent wave surge channels that prohibit safe experimentation. The primary grazers in intertidal communities are molluscs such as limpets, snails and chitons, but also sea urchins in low intertidal to shallow subtidal areas.

Intertidal research has traditionally overlooked the influence that biological oceanographic conditions can have on 
community structure, primarily because competition for space, predator-prey interaction, and low tide abiotic conditions were assumed to have much stronger effects on community structure. Also, oceanographic conditions such as nutrient and phytoplankton concentrations were not known to vary in biologically significant fashion in the nearshore region, because oceanographic measures are typically taken from ships much further offshore.

The importance of large-scale oceanographic transport to larval recruitment in intertidal areas has been more widely recognized. As most organisms within the community have limited or no adult mobility but broadcast their larvae into the water column to develop, the larval input to the community may have little connection to the conditions at the site. Additionally, spawners cannot influence the final destination of their larvae by moving from an unfavorable current, e.g., one where their larvae will be transported to an unsuitable site or where the water conditions are poor, to a favorable one. Therefore, populations can potentially function as sources, providing juveniles to other populations, or as sinks, dependent on other populations for juveniles but producing little on their own. The complicated and oceanographically dependent life cycle of marine plants and animals must be taken into account when designing management strategies. Therefore conservation plans developed within terrestrial ecosystems, where populations are typically more closed, cannot be directly transferred to marine systems (Allison et al. 1998). New conservation strategies have been developed in South America, New Zealand, and North America that center on preserving "source" populations in their conservation plans.

\section{Rocky intertidal ecosystems: North America}

North American rocky shores in the eastern Pacific have not been exploited historically to the extent of South American, though native Americans did harvest intertidal resources and California rocky shores have recently begun to be heavily harvested by southeast Asian immigrants (Simenstad et al. 1978, Knudsen \& Vogel 1997). To this end, we can consider North American rocky shore ecosystems as functioning a manner less directly impacted by human activities. On shores from Canada through California, the California mussel, Mytilus californianus, forms the dominant cover in the mid-intertidal zone. Mytilus californianus is limited at low intertidal levels by predation from the ochre seastar Pisaster ochraceus and at the upper level by physical factors (Paine 1966, 1974, 1976). The mussel achieves a size refuge from its other major predator, whelks in the genus Nucella at higher latitudes, and at even larger sizes from $P$. ochraceus (Paine 1976, Sanford et al. 2003). The barnacle, Balanus glandula, also forms major cover in this zone when mussels are absent. The upper zone is dominated by the barnacles B. glandula and Chthamalus dalli, as well as algae in the genera Fucus, Pelvetia, and Mastocarpus.

Experimental work on western North American rocky shores has elucidated many of the major physical and biotic interactions that contribute to community structure (Paine 1966, Dayton 1971, Paine 1974, 1980, Paine \& Levin 1981, Menge et al. 1994, Robles 1997). Fig. 5 shows a generalized interaction web for lower intertidal rocky shores in central Oregon. Pisaster ochraceus acts as a keystone predator throughout its range via its consumption of $M$. californianus and other invertebrates. Predatory whelks can be important predators when $P$. ochraceus is absent (Navarrete \& Menge 1996). In Southern California, spiny lobsters, Panulirus interruptus, may also prey heavily on mussels, acting as a keystone predator where mussel recruitment rates are high (Robles 1997). Herbivore grazing strongly affects ephemeral algae and the course of benthic succession, but their ability to control macroalgal abundance patterns remains unclear (Robles \& Cubit 1981, Cubit 1984). The controls of herbivore population sizes are poorly understood, but oystercatchers have been shown to influence limpet population structure (Frank 1982, Hahn \& Denny 1989, Wootton 1997). Space is a limiting resource for both algae and sessile invertebrates. Thus, competition for space is a typically a strong interaction both between and within species on exposed rocky shores. However, oceanographic factors may help explain which sessile species dominates at a given site by altering growth and recruitment rates (discussed below).

The role of recruitment in structuring rocky intertidal communities has been a major research focus since the early 1980 s. Roughgarden et al. (1988) documented that variation in oceanographic conditions along the California coast influenced recruitment patterns in the barnacle, $B$. glandula, and that $B$. glandula populations were limited by recruitment in many areas. They also suggested that recruitment patterns were tied to upwelling 


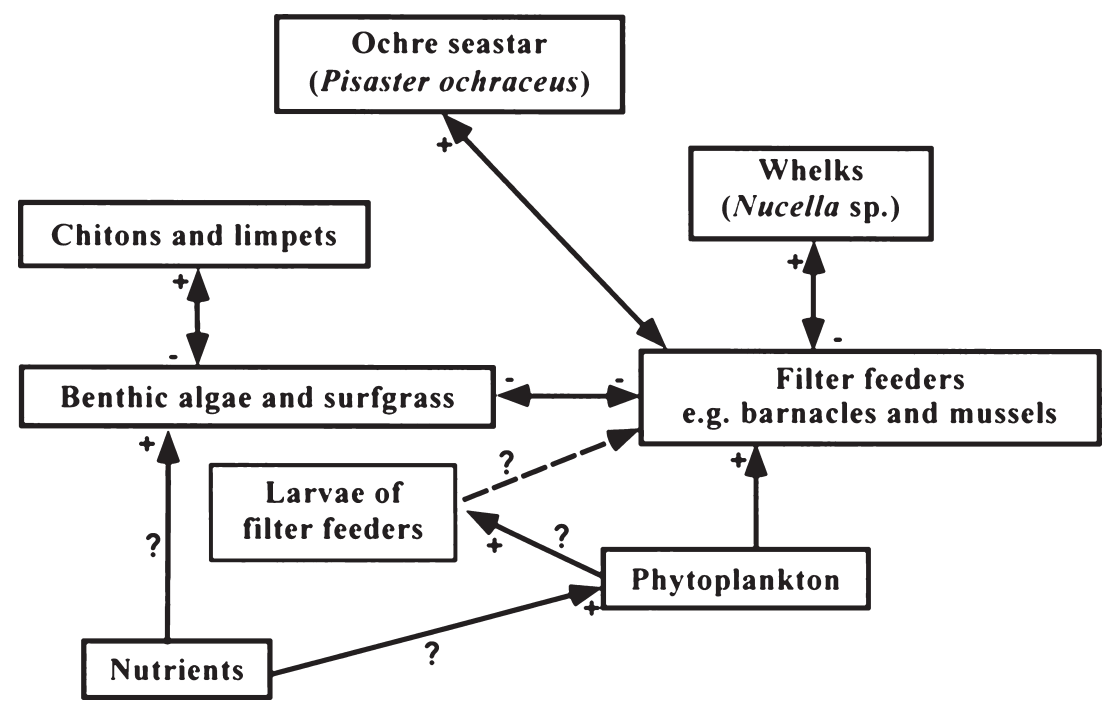

Fig. 5: Interaction web showing direct interactions in the low zone of exposed rocky shores of Oregon, USA. Minus signs indicate negative effects, plus signs indicate positive effects (after Menge et al. 1994).

Trama de interacciones mostrando las interacciones directas en la zona inferior de la costa rocosa expuesta de Oregon, USA. Los signos menos indican efectos negativos, los signos más indican efectos positivos (en base a Menge et al. 1994).

patterns and that both patterns could be disrupted by El Niño conditions. The authors hypothesized, and subsequent data have supported, that larvae produced onshore are advected offshore by upwelled water. Larvae concentrate at the boundary between cold upwelled and warmer offshore surface water as well as in eddies of the California current (Fig. 6). When upwelling winds relax, the larvae are transported back onshore where they consequently settle out of the water column (Roughgarden et al. 1988, Farrell et al. 1991, Roughgarden et al. 1991, Wing et al. 1995). The "tattered curtain" hypothesis (Roughgarden et al. 1991), posits that the length of upwelling relaxations in combination with the width of the upwelling band determine the strength of recruitment at a latitudinal scale. During brief relaxation periods, the upwelling front where larvae concentrate may only reach land in regions where the upwelling band is narrow before upwelling resumes, driving the front offshore again. During the 1982-1983 El Niño, when upwelling decreased along the California coast, intertidal barnacle recruitment increased (Roughgarden et al. 1988). Since the upwelling band is narrower in Oregon and Washington than off of California, the hypothesis may partially explain recruitment differences between the two regions (Roughgarden et al. 1988, Connolly \& Roughgarden 1998). Recruitment rates in Oregon north of Cape
Blanco are an order of magnitude higher that they are in California (Connolly et al. 2001), highlighting the potential importance of oceanographic features to recruitment.

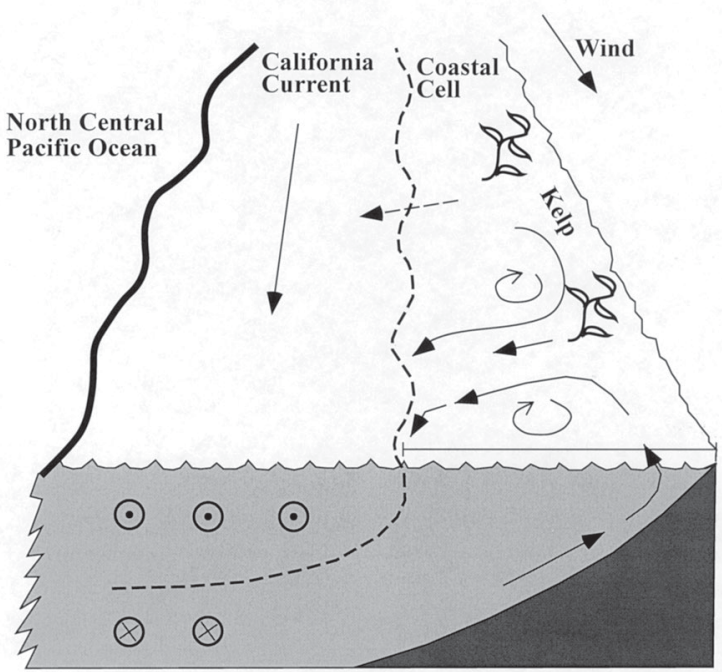

Fig. 6: Schematic diagram of California current system next to the California coast during spring upwelling. Circles with dots indicate southward flow, circles with $\mathrm{x}$ indicates northward flow (after Roughgarden et al. 1988).

Diagrama esquemático del sistema de la corriente de California cercano a la costa de California durante la surgencia de primavera. Los círculos con puntos indican flujos hacia el sur, los círculos con $\mathrm{x}$ indican flujos hacia el norte (en base a Roughgarden et al. 1998). 
Oceanographic patterns may contribute to the patchiness of recruitment in space and time. Upwelling events are episodic throughout the spring and summer, resulting in recruitment pulses. Fig. 7 shows episodes of recruitment for several invertebrate species in relation to upwelling events at Bodega Head, California (Wing et al. 1995). A similar pattern has been observed in barnacles (Farrell et al. 1991, Connolly \& Roughgarden 1998). Squirts and jets of upwelled water associated with headlands may prevent larvae transported with the upwelling front from reaching shore in those areas, increasing patchiness (Roughgarden et al. 1988). Additionally the length and other features of the upwelling band may vary at the mesoscale as well as the latitudinal scale (Menge et al. 1997a).

Mesoscale oceanographic patterns influence the amount of nutrients and phytoplankton delivered onshore to algae and filter feeders. Menge et al. (1997b) determined that on central Oregon shores, Chl-a concentration in the water column were consistently higher at specific locations along the coast. Sampling water at different spatial scales demonstrated that Chl-a varies significantly between locations, i.e., on the scale of tens of kilometers, but only minor variation occurs within sites and benches, i.e., hundreds and tens of meters, respectively. Nutrients varied significantly at the site and location scale, but not consistently; i.e., certain locales did not have consistently high nutrient levels. Also, nutrient levels never fell to the point where they would be considered limiting, at least for phytoplankton. Ch-a concentration peaked in summer months after the relaxation of upwelling events. Potentially, shoreline profile differences and bottom topography affect the degree of upwelling and width of upwelling zones, which in turn affects the quantity of phytoplankton delivered onshore with the upwelling front (Menge et al. 1997a).

Further studies in Oregon have shown that the consistent mesoscale differences in Chl-a concentrations correlate strongly with filter feeder growth. Balanus glandula and $M$. californianus grew faster at a high Chl-a site, Strawberry Hill, than at a low Chl-a site, Boiler Bay (Menge 1992). Physiological studies (Dahlhoff \& Menge 1996) indicate that $M$. californianus growth rates increase sharply at high Chl-a sites after upwelling relaxation events, as indicated by an increase in RNA/ DNA. Potentially, areas with high Chl-a delivery support fast growing mussels and barnacles, enhancing competitive ability and allowing them to dominate space to the exclusion of macroalgae. However, these studies are confounded by recruitment differences between the sites and the unknown effects that nearshore mesoscale oceanographic conditions have on the macroalgae. Experimental enhancement of nutrient levels in the field revealed effects on benthic macroalgal assemblages indicating that shoreline macroalgae, even in upwelling systems, may be more nutrient limited than previously thought (Nielsen 2001, 2003).

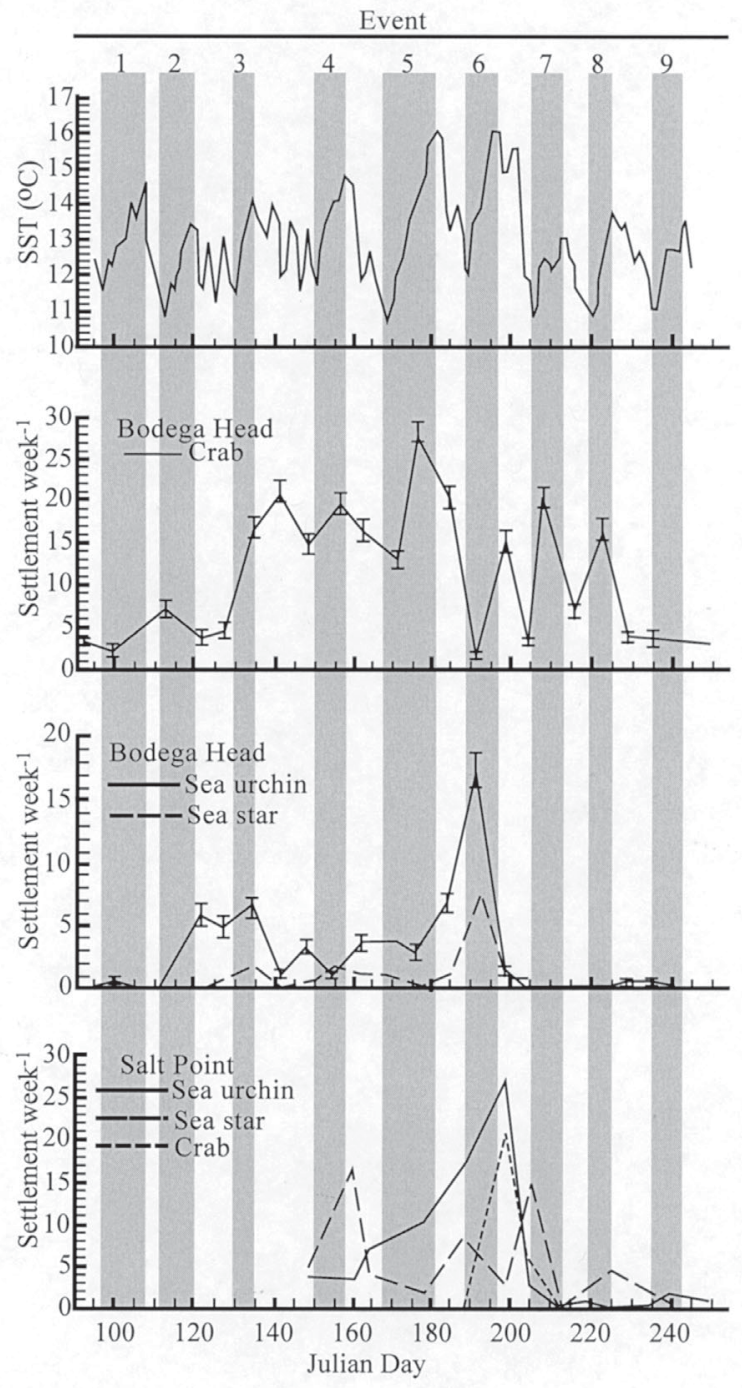

Fig. 7: Water temperature and recruitment of crabs, urchins, and sea stars versus time at Bodega Head and Salt Point, California. Low water temperatures correspond to upwelling periods, numbered and shaded in gray (after Wing et al. 1995).

Temperatura del agua y reclutamiento de cangrejos, erizos y estrellas versus tiempo en Bodega Head y Salt Point, California. Las temperaturas bajas del agua corresponden a períodos de surgencia, numerados y sombreados en gris (en base a Wing et al. 1995). 
El Niño effects on rocky shore communities have been poorly understood, primarily due to the lack of long term monitoring of intertidal biota. Paine (1986) assessed disruptions to the intertidal community at Tatoosh Island, Washington, in the context of El Niño events. He found that while community disruptions occurred during El Niño years, the same disruptions were also caused by extreme weather and oceanographic events not associated with El Niño. For example, El Niño related storms removed large portions of the mussel bed, but severe storms in other years also caused extensive damage. Also, of the four major sea urchin recruitment episodes of the past 20 years, two occurred in El Niño years, and the other two occurred in non-El Niño years, though those years also had unusually warm waters. Elevated sea levels such as those that occur during El Niño rather than temperature (Mysak 1986), appears to coincide with strong urchin recruitment.

The water transported north during ENSO events contains few nutrients, which can detrimentally affect growth of intertidal algae. Additionally, the thermocline and nutricline can deepen, making deep-water nutrients less available (McGowan et al. 1998). Research has indicated that nutrients for microalgae might become limiting during El Niño summers (Wootton et al. 1996). Laminarian algal species appear to be the most susceptible (Gunnill 1985). Algae weakened by the nutrient poor water might then suffer severe damage during subsequent boreal winter storms. However, as Paine (1986) suggested for mussels, consistent effects of El Niño on macroalgae in the rocky intertidal are difficult to separate from seasonal and interannual variability.

Dayton \& Tegner (1990) speculated on why intertidal communities might be resistant to the severe perturbation that El Niño events have on other ecosystems. They hypothesized that intertidal plants and animals have evolved in the context of severe physical conditions such as wave action and heat stress. Most intertidal algae can regenerate from their holdfasts and can recover from large loss of biomass due to storm damage or nutrient starvation. Moreover, the elevated sea levels associated with ENSOs may mitigate the increased temperature effects on intertidal organisms by decreasing exposure to low tide thermal stress.

The potential effects of global warming on North American rocky shores have just begun to be studied (Ray et al. 1992). Comparisons between 1931-1933 and 1993-1994 census of intertidal biota at a site in Monterey Bay,
California, indicate that biotic changes have occurred in the intervening time period (Barry et al. 1995, Sagarin et al. 1999). Significantly, there was a greater tendency for southern species to extend their range northward into Monterey than for northern species to extend their range southward. Concurrently, mean and maximum shoreline water temperatures increased by 0.75 and $2.2{ }^{\circ} \mathrm{C}$, respectively. Therefore, one consequence of global warming may be latitudinal shifts in species ranges. However, Denny \& Paine (1998) pointed out that the two samples taken in the study were at different phases of the Metonic cycle. Since the Metonic cycle influences the duration and timing of low tide exposure, the study may be confounded by variation in low-tide physical stress caused by the cycle. Sagarin et al. (1999) attempted to account for the problems associated with a lack of continuous data at the Monterey site. While their analyses provide a strong inference that climate change is affecting the community, they also point to the importance of both sustained biological monitoring and biologically relevant thermal modeling. Recent data on mussel body temperatures modeled through thermal "mimics," show no increase of maximal body temperature with latitude, and that the highest body temperatures occurred during low tide (Helmuth et al. 2002). These data indicate that terrestrial climatic conditions may impact organismal body temperature more than increases in water temperature. In contrast, Sanford (1999) documented that the moderate water temperature fluctuations $\left(8-14{ }^{\circ} \mathrm{C}\right)$ associated with normal upwelling events on the Oregon coast have dramatic behavioral impacts on $P$. ochraceus. Since $P$. ochraceus is a keystone predator, even minor water temperature changes or modification of upwelling patterns can have wide community effects.

Climate change models also predict an increased rate of sea level rise, through thermal expansion of the water and melting of ice over the Antarctic (Beatly 1991). Currently sea level is rising at $0.9 \pm 0.2 \mathrm{~mm}$ per year on the southern California coast (Roemmich 1992). The rise and fall of water with the tides determine the distribution of intertidal animals and plants. A change in sea level rise would impact intertidal organisms significantly. Sudden changes of tidal height have been documented due to coseismic uplift in Chile and Alaska, where earthquakes raised intertidal areas in relation to sea level (Castilla 1988). These sudden catastrophic changes had severe 
impacts on the intertidal communities. The ability of communities to change in relation to more gradual sea level rise is not known. A determining factor will probably be the availability of suitable substrate in "new" intertidal zones.

Global warming has also been predicted to affect the degree of upwelling along the North American coast. Hypothetically, upwelling might increase as climate warming increases wind stresses along the coast (Bakun 1990) and there is evidence indicating that upwelling has increased in the northeastern Pacific even as ocean temperatures have increased (Schwing \& Mendelssohn 1997). However, it has also been posited that due to a deepened thermocline, the upwelled water will be warmer and less nutrient rich (Roemmich \& McGowan 1995). Changes in upwelling patterns would effect recruitment, delivery of Chl-a, and average onshore water temperatures during the spring and summer. Additionally, upwelling influences the onshore terrestrial climate. During upwelling, foggy cool conditions prevail along coastlines, ameliorating potentially stressful low tide conditions (Bakun 1990). Alterations in upwelling patterns could therefore significantly alter the physical conditions at both high and low tide for intertidal organisms.

The Metonic cycle affects water temperature and the duration of aerial exposure by intertidal organisms (Denny \& Paine 1998, Helmuth et al. 2002). During periods when lunar declination is at a maximum, tidal fluctuations are smaller and onshore water temperatures are lower than when lunar declination is at a minimum. Calculated exposure times for Monterey Bay organisms may change by nearly $50 \%$ depending on the phase of the Metonic cycle. On Tatoosh Island, Washington, the Metonic cycle helps to explain variation in changes in the upper limit of mussel distribution. Consistent long term monitoring of intertidal sites is required to better understand the responses of intertidal communities to climate change, ENSOs, and long period climactic fluctuations. Additionally, the effect of the PDO on northeastern Pacific rocky shores are also unknown, but is most likely to effect recruitment patterns of species with planktonic larvae via effects on the California current and larval transport.

\section{Rocky intertidal ecosystems: South America}

South American intertidal communities share many qualities with North American systems.
For many trophic and tidal levels the major phyla are the same (Broitman et al. 2001). At high to mid intertidal areas, barnacles such as Jehlius cirratus, Balanus laevis, and Balanus flosculus dominate. Grazers such as fissurellid limpets and chitons exert strong effects on the system (Jara \& Moreno 1984). At slightly lower levels, chorito maico (mussel), Perumytilus purpuratus, persists when not eaten by the predaceous loco (muricid gastropod), Concholepas concholepas (Moreno et al. 1986, Durán \& Castilla 1989). The crustose green alga Codium dimorphum also forms a major portion of the cover (Santelices et al. 1981). In the low zone, the large macroalgae chascón, Lessonia nigrescens, and conchayuyo, Durvillea antarctica, comprise the primary cover, with L. nigrescens having greater abundance at more wave swept sites than D. antarctica (Santelices et al. 1980). Other important predators, include the seastars Stichaster striatus, Meyenaster gelatinosus, and particularly the sol de mar (sun star), Heliaster helianthus (Navarrete \& Castilla 2003). The pejesapo, $S$. sanguinus, consumes most organisms attached to the rocks in its grazing area, including barnacles, mussels, and algae.

A generalized interaction web for the midintertidal in Chile is given in Fig. 8 (after Moreno 1986, Moreno et al. 1986, Durán et al. 1987, Durán \& Castilla 1989, Godoy \& Moreno 1989). When not heavily fished by humans, locos exert strong top down control on mussels and barnacles (Moreno et al. 1986). Similarly, lapas (keyhole limpets, Fissurella spp.) graze heavily on algae when humans do not drastically reduce populations. In reserves where harvesting is prohibited, grazing by fissurellid limpets restrict the red alga, Iridea boryana, to refuge habitats (Moreno \& Jaramillo 1983). In the absence of herbivory, $I$. boryana forms a dominant part of the cover (Jara \& Moreno 1984). Fissurellid limpets compete heavily with patellid limpets (Collisella spp.) and pulmonate gastropods (Siphonaria spp.) (Moreno \& Jaramillo 1983, Godoy \& Moreno 1989).

As indicated above, humans have had dramatic impacts on the structure of intertidal communities in Chile (Moreno 1986, Moreno et al. 1986, Durán et al. 1987, Durán \& Castilla 1989, Godoy \& Moreno 1989, Castilla 1999). Locos, whelks, limpets, urchins, picorocos (large barnacle, Austromegalobalanus psittacus), mussels, and several species of seaweed in the genera Lessonia, Durvillea, Mazzaella, and Gelidium are all harvested (Durán et al. 1987, Santelices \& Norambuena 
1987, Hoffmann \& Santelices 1997). Sixty thousand tons of Lessonia and 300-500 tons of Gelidium are harvested yearly for export of alginate and agar respectively. Approximately 430 tons of $D$. antarctica are harvested for food yearly (Hoffmann \& Santelices 1997).

In the 1980 s increased human harvesting, perhaps in combination with ENSO events, severely threatened the loco and Lessonia harvests. In the case of the loco, increased foreign demands caused prices to skyrocket, increasing fishing pressure (Fig. 9). Both loco and Lessonia populations declined sharply at the time of the 1982-1983 El Niño (Fig. 10 and 11). However, the fishery was under severe human pressure at the time and may have collapsed for this reason alone (Castilla \& Camus 1992). Data indicate that loco populations exhibit reduced recruitment when the ENSO index is either strongly negative or positive (Moreno et al. 1998). Upwelling events, rather than relaxation events, may advect loco larvae onto shore due to migration of the larvae into deeper waters at night (Poulin et al. 2002a, Poulin et al. 2002b). Concurrent with the collapse of the loco, pulpo (octopus) landings increased dramatically (Fig. 10). Although ENSO events have been documented to have severe effects on Peruvian and northern Chilean rocky shores (Soto 1985, Tomicic 1985, Arntz \& Tarazona 1990), the more temperate rocky shores of central and southern Chile may be less directly effected (Navarrete et al. 2002).
The crash of the loco fishery led to the institution of new fishery practices in Chile. Two key elements are part of this plan: local control of resources in coordination with central government and the establishment of marine protected areas and reserves (Castilla 1994, Castilla \& Fernández 1998, Castilla 2000, Castilla \& Defeo 2001). Establishing local control puts regulation of fisheries in the hands of those who both have a long term interest in the fishery and are on site to enforce rules. The marine protected areas establish larval sources for outside populations that are exploited. Success hinges on establishing a sufficient number of enforced reserves to support a sustainable fishery outside the protected areas (Castilla 2000, Fernández et al. 2000). Local artisanal fishing collectives manage reserves and enforce policies, in conjunction with national coordination of the collectives.

"No take" reserves and protected areas have also been a boon to experimental ecology in Chile. Reserves that prohibit fishing have helped document the severe impact that human intervention has had outside the reserves. In particular, within reserve areas have lower macroalgal and mussel cover due to greatly increased herbivory and predation (Moreno et al. 1986, Durán \& Castilla 1989). Additionally, reserves can potentially seed non-reserve areas through the increased population size and body size of protected species, such as the loco (Manríquez \& Castilla 2001).

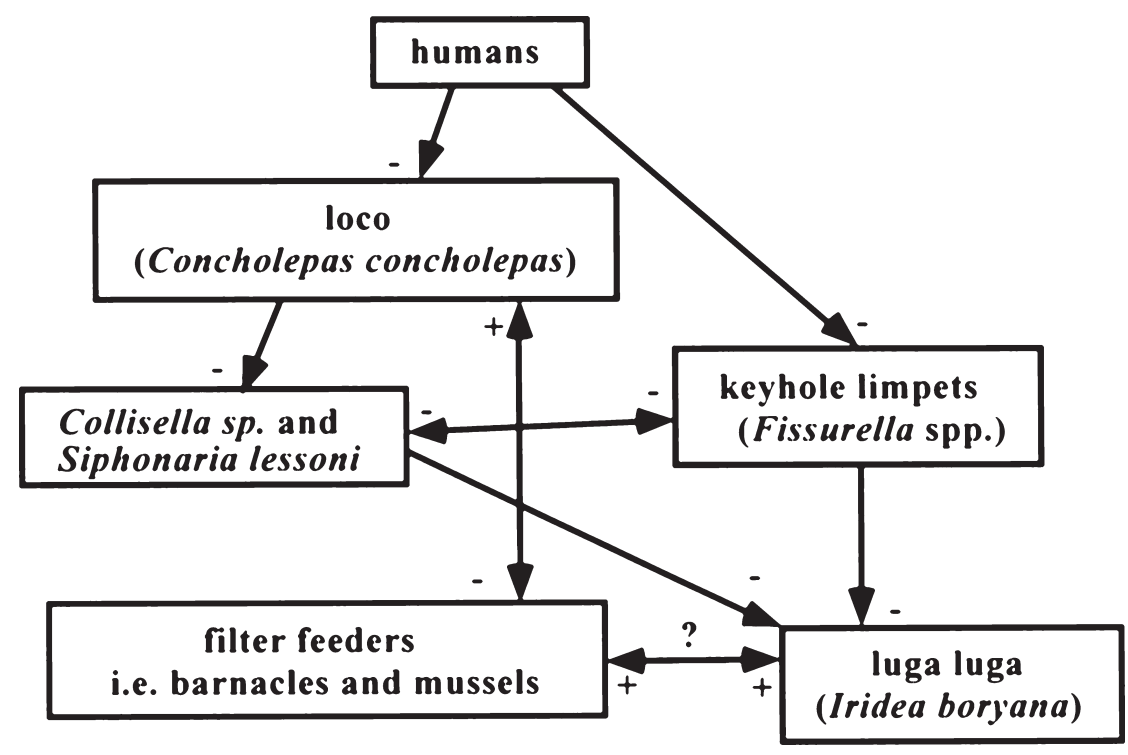

Fig. 8: Interaction web for central Chilean mid rocky intertidal. Minus signs indicate negative effects, plus signs indicate positive effects (after Moreno et al. 1986).

Trama de interacciones para el intermareal rocoso medio de Chile central. Los signos menos indican efectos negativos, los signos más indican efectos positivos (en base a Moreno et al. 1986). 


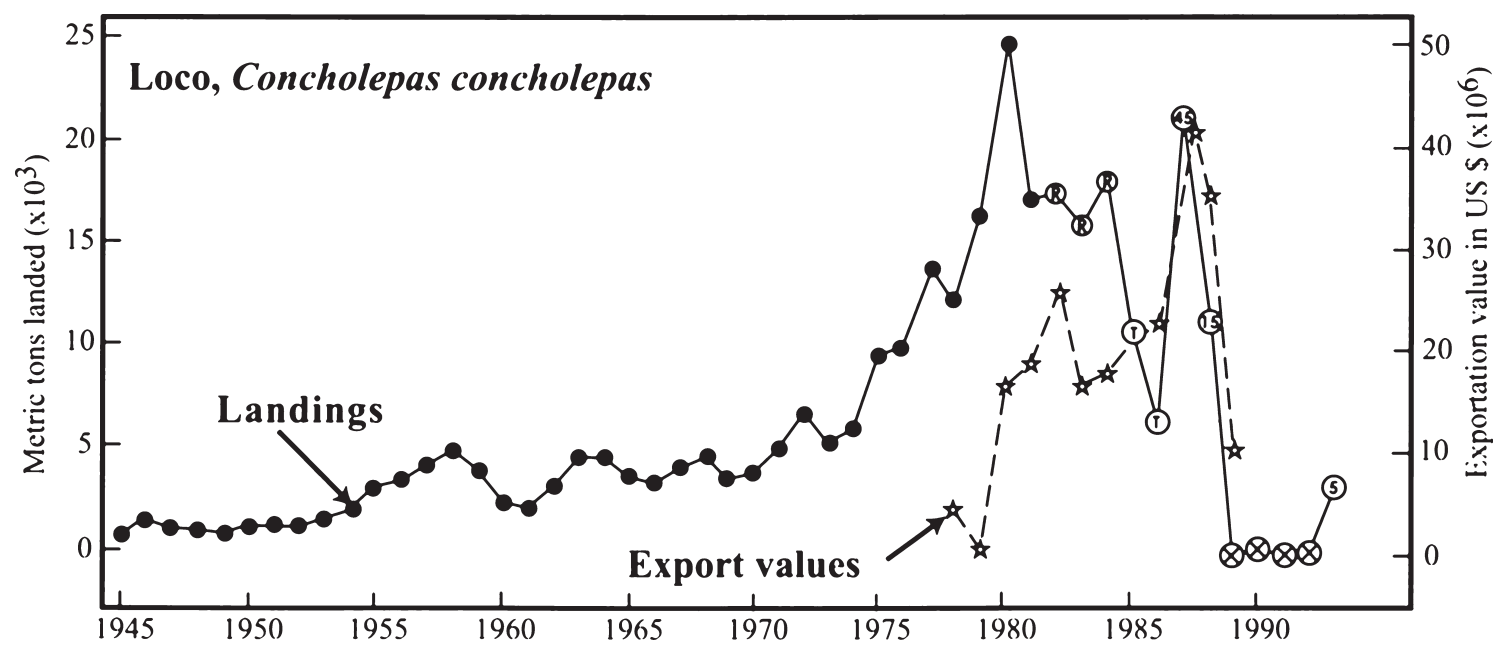

Fig. 9: Landings of the loco, Concholepas concholepas (left axis) and export value of the fishery (right axis) versus time. For landings: $\bullet=$ fishery open all year, $\mathrm{R}=$ fishery closed during reproductive season, $\mathrm{T}=$ fishery closed most of year and opened under a 4,000 tons quota, $45=$ fishery open 45 days, 15 = fishery open 15 days, $\mathrm{x}=$ fishery closed, $5=$ fishery open for 5 days (redrawn from Castilla 1994).

Desembarcos de loco, Concholepas concholepas (eje izquierdo) y valor de exportación de la pesquería (eje derecho) versus tiempo. Para desembarcos: = pesquería abierta todo el año, $\mathrm{R}=$ pesquería cerrada durante la estación reproductiva, $\mathrm{T}=$ pesquería cerrada la mayor parte del año y abierta bajo un régimen de cuota de 4.000 toneladas, $45=$ pesquería abierta 45 días, 15 = pesquería abierta 15 días, $\mathrm{x}$ = pesquería cerrada, 5 = pesquería abierta por 5 días (redibujado de Castilla 1994).

\section{Kelp forests: common features}

Kelp forests of Macrocystis spp., Nereocystis leutkeana and other laminarian species grow in many regions of the world including New Zealand, Australia, southern ocean islands, and the western coasts of South and North America. Macrocystis pyrifera forms the majority of kelp forests in South America and in the northern hemisphere from San Francisco Bay south to Baja California. Nereocystis dominates from San Francisco Bay through Oregon and Washington, with Macrocystis integrifolia becoming abundant in Alaska. The third species of Macrocystis, Macrocystis augustifolia, occurs in South American and Californian waters (Neushul 1971). Other laminarian kelps, particularly in the genera Laminaria, Alaria, and Lessonia also form important subtidal kelp beds (Estes \& Duggins 1995, Vásquez \& Buschmann 1997). Kelp forests are very productive communities and fulfill important ecological and economic functions. Kelp forests provide complex threedimensional habitat and therefore allow extensive spatial partitioning by species and high species diversity (Bodkin 1989). Economically Macrocystis is harvested in the both hemispheres for gelling compounds, as well as providing habitat for fish and shellfish. Recreational SCUBA diving centering on kelp forests, particularly in California and Puget Sound, contributes to local tourist industries.

Giant kelps as well as smaller understory macroalgae generate the bulk of primary production in kelp forests. Phytoplankton production may also be high, and kelp forests routinely support an array of filter feeders such as bryozoans, sponges, and tunicates. Thus, kelp forests form important nearshore atmospheric carbon sinks. Kelp forests may also be important exporters of fixed carbon to other oceanic ecosystems through production of drift algae that can feed herbivores in other ecosystems, and production of suspended detritus that can feed filter feeders (Rodriguez 2003). Carbon export may also occur as small fish grown within the kelp forest migrate to other habitats as they age.

Macrocystis and Nereocystis, like other laminarian algae, exhibit a complex life cycle, consisting of an alternation between very small gametophytes and the large sporophytes that form forests. Gametophytes require specific light and temperature regimes to grow and reproduce. Low red light levels support the most growth in field studies (Graham 1996). In contrast, sporophytes need more 
light, high nutrient levels and sufficient water motion to enhance nutrient uptake and photosynthesis, but low enough to not risk scour or breakage. All these variables are affected by oceanographic regimes. Additionally, kelp forests require hard substrata on which to grow (Schiel \& Foster 1986). Sporophytes recruit to a variety of substrates, but must grow on hard substrates to survive. In many areas kelps are considered limited by substratum availability.

Sea urchins are the most ubiquitous of kelp forest herbivores, and the ones documented to have the strongest effects (Ebeling et al. 1985, Harrold \& Reed 1985, Dayton et al. 1992, Estes \& Duggins 1995, Tegner et al. 1995). Urchins not only amass large numbers when recruitment

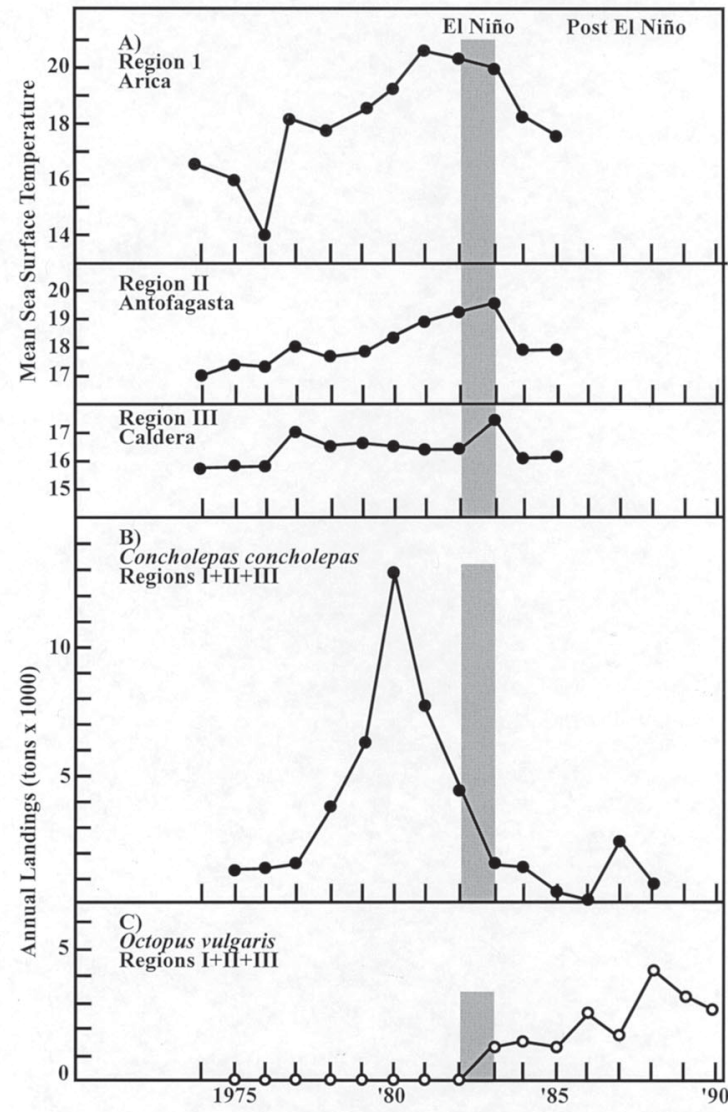

Fig. 10: (A) Mean sea surface temperature in three Chilean northern regions; (B) annual landings of loco in the three regions; (C) Octopus landings in the three regions (after Castilla \& Camus 1992).

(A) Temperatura media superficial del mar en tres regiones del norte de Chile; (B) desembarcos anuales de loco en las tres regiones; (C) desembarcos de pulpos en las tres regiones (en base a Castilla \& Camus 1992). is high and predation low, but also attack the kelp holdfast, destroying the entire plant. In contrast, many other kelp forest herbivores, such as topsnails, live in the kelp canopy and consume only a minor portion of the plant. Other herbivores include abalone, chitons and other gastropods, as well as fish. Fish, lobster, sea stars, and sea mammals generally occupy upper trophic levels in kelp communities.

Kelp forests are influenced by oceanographic factors in several ways. Flow of nutrients and larvae into the kelp forests have widespread community effects. Additionally, damage by storms can remove large amount of kelp biomass from the forests, much of it becoming drift algae exported to herbivores within and without the forest.

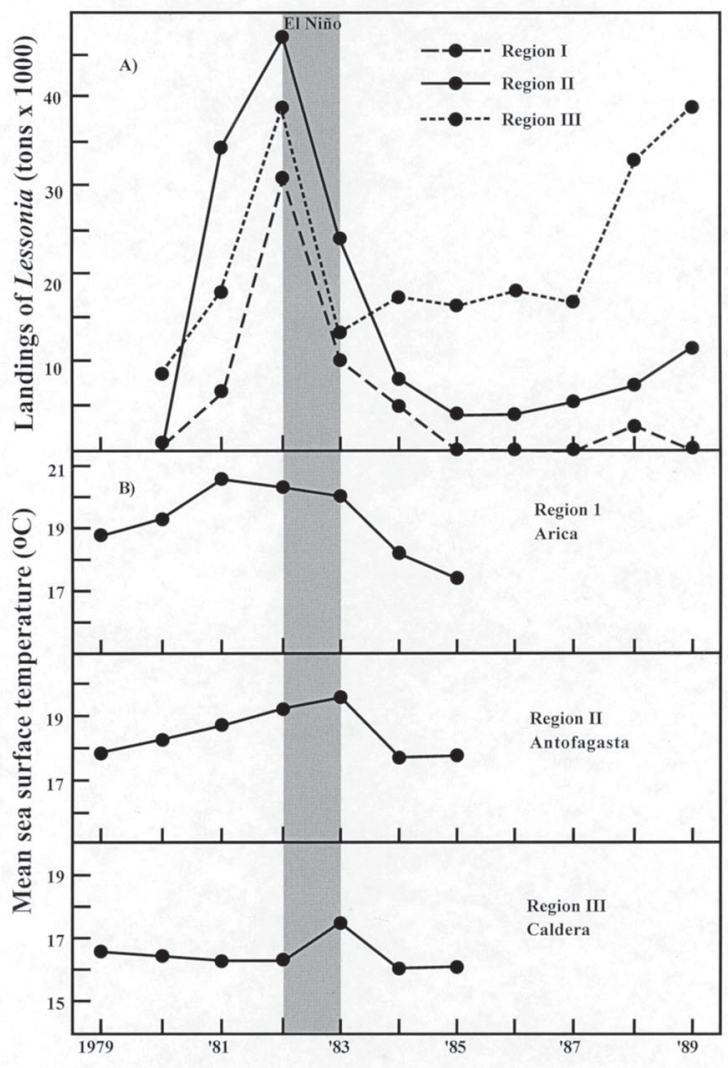

Fig. 11: (A) Annual landings of the kelp Lessonia nigrescens, and (B) mean sea surface temperatures in the three far northern regions of Chile (after Castilla \& Camus 1992).

(A) Desembarcos anuales del alga Lessonia nigrescens y (B) temperatura media superficial del mar en las tres regiones del extremo norte de Chile (en base a Castilla \& Camus 1992). 


\section{Kelp forests: North America}

The bulk of information on North American kelp forests comes from studies in central to southern California waters and Alaska. In particular the kelp beds off of Monterey and San Diego, California, where the Hopkins Marine Station and Scripps Oceanographic Institute, respectively, are located, and the Aleutian Islands in Alaska have received considerable long term study. Less is known about kelp stands on the open coasts of Washington and Oregon, possibly due to the relative lack of Macrocystis spp. as compared to Nereocystis, and the logistical difficulty of diving research in these areas.

Macrocystis pyrifera dominates the kelp forests in California. A generalized food web for a southern California kelp forest is given in Fig. 12 (after Cohen et al. 1990). Note that, as opposed to the interaction webs shown previously, food webs do not indicate interactions other than predator-prey. Biotically the primary regulator of kelp abundance is the purple sea urchin, Strongylocentrotus purpuratus, and to a lesser extent the red sea urchin, S. franciscanus. Because they attack the kelp holdfast, urchins are capable of removing entire kelp stipes and creating "urchin barrens" where only grazing-resistant coralline algae survive (Ebeling et al. 1985). A number of factors are important in regulating urchin abundance, both biotic and physical.

The interaction between sea otters, urchins, and kelps is well known. When drift algae is abundant, urchins tend to stay in their crevices and feed. When drift algae became scarce through oceanographic factors and increased competition for food, urchins began to actively forage, removing large areas of kelp (Ebeling et al. 1985, Harrold \& Reed 1985, Watanabe \& Harrold 1991). At sites where sea otters, Enhydra lutris, are abundant, urchin populations can be reduced to levels that allow for enhanced kelp survival (Mclean 1962, Estes \& Palmisano 1974, Estes et al. 1978, Duggins 1980, Breen et al. 1982, Pearse \& Hines 1987, Laur et al. 1988, Oshurkov et al. 1988, Duggins et al. 1989, Estes \& Duggins 1995). In the last century through to the early part of this

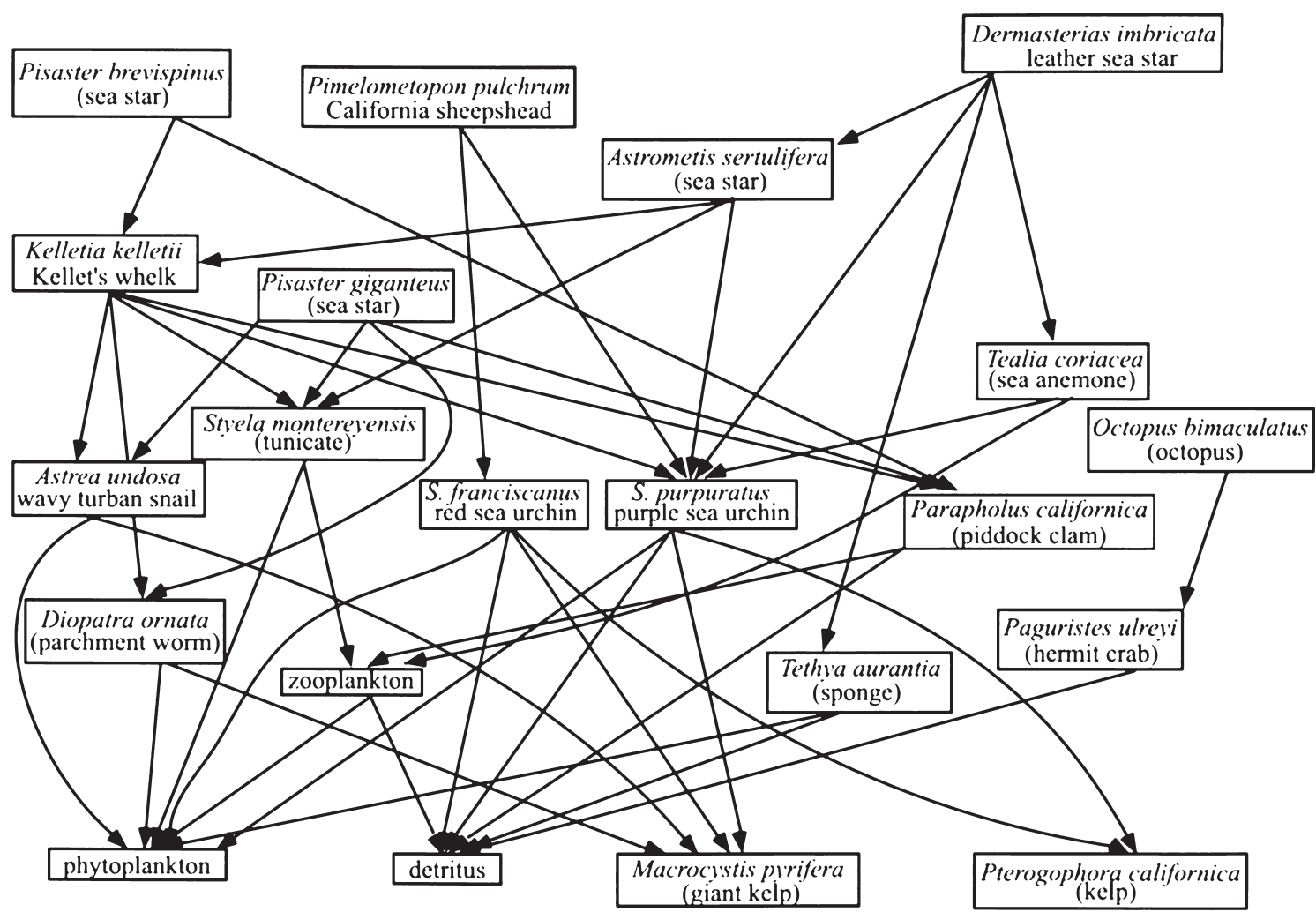

Fig. 12: Food web for a southern California kelp forest. Arrows show consumer -food interactions only (data from Cohen et al. 1990).

Trama trófica de un bosque de algas pardas en el sur de California. Las flechas muestran interacciones consumidoralimento solamente (datos de Cohen et al. 1990). 
century, sea otters were driven extinct throughout most of their range on the North American coast. The cessation of otter hunting allowed reintroduction of the otter to some of its former range in California and Alaska. Subsequent regulation of the urchin populations by sea otter predation has strong positive effects on kelp abundances in areas of otter reintroduction (Estes \& Palmisano 1974, Estes \& Duggins 1995).

Even with sea otter re-introduction, urchin barrens may persist until storms, disease, and recruitment failures reduce urchin numbers. These factors can also facilitate kelp forest reestablishment in urchin barrens outside of current sea-otter geographic range (Ebeling et al. 1985). Large and mesoscale oceanographic factors have a strong influence on urchin recruitment. Areas with strong offshore flow such as capes and headlands show low and unpredictable recruitment patterns (Ebert \& Russell 1988, Wing et al. 1995). Areas between headlands may receive strong annual pulses. El Niño disrupts recruitment of sea urchins, either through changing current patterns or because the warm nutrient poor water associated with El Niño is not conducive to larval survival.

The effects of El Niño on Macrocystis have been well documented (see Tegner \& Dayton 1987, Dayton \& Tegner 1990 for review). Kelp forests are impacted directly through increased storm activity during the winter and through delivery of warm, nutrient-poor water in summer, and indirectly through the subsequent effects on urchin populations (Dayton \& Tegner 1984, Dayton et al. 1999). El Niño generated storms can remove large amounts of kelp biomass from a forest or remove entire stands (Dayton \& Tegner 1984, Dayton et al. 1992, Stull 1995). During the summers of El Niño years, kelps may undergo further die offs due to nutrient limitation, particularly of nitrogen (Dayton et al. 1999). The effect of elevated temperature is not considered to be as severe as that of nutrient depletion, but there is some evidence that it may make the kelps more vulnerable to disease (North 1983). Very young "blade stage" Macrocystis have been observed to have enhanced growth rates during El Niño, perhaps because water clarity is greater and nutrients may be less limiting at the kelp forest bottom (Schroeter et al. 1995). In southern California, El Niño storms cause increases in the pollutants delivered to coastal areas through increased runoff (Stull 1995, Maurer \& Nguyen 1997), though the effects of this are unknown.

The extensive biomass removal due to $\mathrm{El}$ Niño effects within the kelp stands results in lower drift algae available for urchins (Dayton et al. 1992). Consequently, urchins begin to forage outside of crevices and within the bed as described above. Thus, even more kelp biomass is lost as the urchins feed. In this fashion, stable urchin barrens may be created (Dayton et al. 1992), although most sites recover quickly from El Niño via subsequent kelp recruitment. Urchins are capable of maintaining barrens until the population is reduced by disease or other mortality, after which Macrocystis again dominates (Dayton et al. 1992). Other effects of El Niño on kelp forest communities include decreased recruitment of red abalone, Haliotis rufescens; increased recruitment of pink abalone, $H$. corrugata, spiny lobster, Panulirus interruptus, and the California sheepshead wrasse, Semicossyphus pulcher; and declines in the abundances of sea stars species Patiria miniata, P. ochraceus, and Dermasterias imbricata. In Baja California, severe El Niño corresponded to Macrocystis loss and recruitment failure of abalone, perhaps because Macrocystis aids in local larval retention (Shepherd et al. 1998).

Human activities impacting kelp forests in North America include kelp harvesting; commercial fisheries for abalone, sea urchins, fish; sport fishing for lobster and fish; and sewage runoff. Historically, sea otter hunting had devastating effects on kelp forests as mentioned above. In southern California, Macrocystis beds where sea otters are absent, urchin populations are heavily preyed upon by the California sheepshead wrasse and spiny lobster, both of which are fished by humans (Tegner \& Dayton 1981). A number of other upper trophic level species have been heavily fished in and around kelp forests, such as rock fish, seabass, and sharks. But since baseline data are limited and all change occurs within the context of larger scale oceanographic dynamics, full assessment of human impacts is difficult (Dayton et al. 1998). Abalone populations of all species have been severely overfished, to near the point of extinction in the case of white abalone, Haliotis sorensii, listed as endangered in 2001 (Davis et al. 1996, NOAA 2001, Rogers-Bennett et al. 2002a).

Kelp has been harvested off of North America since the early part of the 20th century, primarily for potash. During WWI kelp forests were heavily exploited for potash, acetone, and charcoal. After the war the market for those kelp products collapsed and gradually algin became the primary commercial kelp product. The value of kelp algin production has historically rivaled that of the offshore fisheries 
(North 1971). Generally, kelp boats harvest the top portion of kelp stipes, allowing kelp survival and maintenance of the three dimensional ecosystem structure. However, productivity is lost with kelp harvesting due to tissue loss, particularly of the most heavily photosynthesizing parts, those at the surface.

While sea otter reintroduction is regarded both as a highly successful recovery and cautionary tale about species exploitation, three caveats must be added. One is that sea otters have yet to occupy the full extent of their former range. The region from northern California to Vancouver Island still lacks viable otter populations. Secondly, sea otters are currently in decline in areas of Alaska from heavy predation by killer whales, Orcinus orca. Killer whales have apparently changed diet as populations of their preferred prey, pinnipeds, have declined (Estes et al. 1998, Doroff et al. 2003). Lastly, the fishery for red sea urchins became highly profitable in the 1980's due to American and Japanese demand for the roe (Kato \& Schroeter 1985, Pfister \& Bradbury 1996). The fishery quickly became over-fished in California and has declined precipitously since 1988 (Botsford et al. 1999), though it remains the second-most top grossing fishery in California (Rogers-Bennett et al. 2002b). Sea otter reintroduction plans are often met with resistance by urchin fishers, who view the otters as competitors.

It is not known how global climate change will impact kelp communities. As mentioned previously, some conceptual models of climate change predict increased upwelling (Bakun 1990). If, as Roemmich \& McGowan (1995) suggest, upwelled water becomes warm and has insufficient nutrients to sustain the kelps, forests would be severely adversely affected. Conversely, if upwelled water is cool and contains sufficient nutrients, the increased upwelling may buffer other effects of climate change. Climate change models also predict increased storm activity, which would increase physical kelp damage, and increased frequency of El Niño, which would starve kelps of nutrients. Additionally, California Channel Island black abalone populations have suffered serious declines due to "withering syndrome" since the late 1980's. Caused by a Rickettsiales-like prokaryote, water temperature appears to be the strongest environmental correlate with disease severity (Moore et al. 2002). Increased sea temperatures due to either global warming or frequent El Niño would impact negatively on abalone populations through disease or other factors
(Harvell et al. 1999, Hobday \& Tegner 2002, Moore et al. 2002).

\section{Kelp forests: South America}

The kelp forests off of the South American west coast are not as extensive or diverse as those off of North America. Nor have they been as extensively exploited commercially, although they are harvested for alginate. This may be due to the more patchy distribution of Macrocystis off South America, or because Lessonia is more abundant and accessible. Lessonia forms highly diverse "forests" of its own in the shallow subtidal and low intertidal. Vásquez \& Buschmann (1997) provide a review of work on Chilean subtidal kelp beds.

Macrocystis forms beds all along the Chilean and southern Peruvian coast, but is most abundant south of $42^{\circ}$. Consequently, the majority of studies on Macrocystis have been conducted in southern Chile. In many areas off South America, Macrocystis stands are decimated on an annual basis, due to storm activity (Moreno \& Sutherland 1982), or unknown factors. At a site in southern Chile, the depth of the shallow edge of Macrocystis beds appeared to be set through competition with Lessonia vadosa, and its deep edge through a combination of substrate availability and competition with Lessonia flavicans (Santelices \& Ojeda 1984). The role of nutrient limitation in general or in conjunction with ENSO events has been little studied (Vásquez \& Buschmann 1997).

Unlike their northern hemisphere counterparts, the South American otter, the sea cat Lontra felina, does not prey on sea urchins (Cohen et al. 1990) and is not a keystone predator. However, data on the role of sea urchins in regulating South American Macrocystis communities is equivocal (see Vásquez \& Buschmann 1997 for review of herbivory in Chilean Lessonia and Macrocystis beds). Moreno \& Sutherland (1982) found that neither the urchin Loxechinus albus nor the snail Tegula atra played a strong role in regulating Macrocystis. Castilla \& Moreno (1982) ${ }^{1}$ obtained similar results in southern Chile. Both studies found that, similar to the northern hemisphere, urchins subsisted on abundant drift kelp and

CASTILLA JC \& CA MORENO (1982) Sea urchins and Macrocystis pyrifera: experimental test of their ecological relations in southern Chile. Lawrence JM (ed) International Echinoderms Conference: 552. AA Balkema, Rotterdam, The Netherlands. 
evidently did not need to actively forage on standing kelp. However no information is available on grazing activity when drift kelp become limiting.

In contrast, Dayton (1985) found strong effects of $L$. albus between $54-46^{\circ} \mathrm{S}$ in wave exposed areas. Macrocystis stands developed in areas where urchins were harvested. He hypothesized that south of $54^{\circ} \mathrm{S}$ recruitment of L. albus was extremely low, and the populations never grow to the point where kelps are eliminated. Two factors were put forward to possibly account for low urchin recruitment. One is that the extensive freshwater runoff from the coastal fjords creates water conditions averse to urchin larvae. Alternatively the west wind drift, which hits the South American coast north of where the kelp forests become abundant, may carry the majority of urchin larvae off the coast towards Antarctica (Dayton 1985)

Clearly more research needs to be done on factors affecting kelp communities in South America and on interactions among factors. Further study of the interactions of nutrient availability, drift kelp availability, storm damage, and urchin grazing would be particularly valuable. El Niño effects on kelp forests have also been little studied in South America. Arntz \& Tarazona (1990) reported that a Macrocystis stands in Peru were devastated during the 1982-1983 ENSO, but other data are lacking.

\section{Pelagic ecosystems}

Intuitively, open water ecosystems would seem to be those most likely to be directly impacted by oceanographic changes. The water mass within which the organisms exist provides the physical conditions of their environment, including transport, nutrients, and food. Unlike benthic communities, space is not considered limiting. However, due to the logistical difficulties of open water experimentation, little experimental work has been done to elucidate interaction webs in these communities. Much data has been collected on plankton abundances as they are oceanographically informative, and fisheries research provides considerable data on the abundance and diet of commercially important fish.

Primary productivity in these communities derives from phytoplankton, while fish and marine mammals generally occupy the top trophic levels. Organisms at lower trophic levels, such as plankton, are small with weak or no swimming ability, and tend to move with the water mass. Lower trophic level populations change on an annual and interannual scale in response to local environmental conditions, since these species are short lived and have limited mobility. Satellite color data from 1979-1986 showed that El Niño negatively impact phytoplankton populations, except in a narrow region next to the coast, by creating a warmer, deeper mixed layer. El Niño accounted for most of the interannual variability in phytoplankton concentration (Fiedler 1984, Strub et al. 1990). More recent direct measurements off central California following the 1992 El Niño give essentially the same results (Chavez 1996). As described above, CalCOFI data indicate that zooplankton populations also respond to changes during and following El Niño years (Chelton et al. 1982, Roemmich \& McGowan 1995). The primary result from the CalCOFI studies was that lower equatorward flow and warmer water during El Niño years resulted in lower zooplankton populations off central and southern California.

Fish species are longer lived and can migrate long distances, making use of geographic differences in physical forcing and circulation. Thus, they can respond to both annual and interannual variability in environmental conditions by spawning in areas best suited for larval survival, and subsequently migrating to more productive regions to feed. In the California current, the preferred spawning area for many species is the quiescent and thermally stratified southern California bight. Over most of the past several decades, observations have shown that both small pelagic species, such as sardine and anchovy, and larger fish, such as hake, migrate to the bight to spawn. Adults and juveniles then migrate into the more strongly forced, turbulent and advective regions north of the bight, where upwelling produces much higher concentrations of phytoplankton and zooplankton inshore of the core of the California current.

Interannual variability in fish catch is not usually as clearly related to environmental conditions during a given year as phytoplankton and zooplankton abundances are. Although this may be partially due to the confounding effects of changing fishing pressure and strategies, other factors may be at work such as the longer life span and higher mobility of fish mentioned above. For example, a strong year-class from a good year before an El Niño can result in a large population, some of which are caught during the poorer El Niño conditions and others of which 
survive and provide continuity of the population size through the poor conditions, a "storage effect." Thus, although annual survival of the larval stages of a population may correlate well with interannual variability in conditions, fish catch and adult populations may not. Additionally, since the community interactions of pelagic communities are poorly understood, the reaction of fish populations to physical changes may be mediated by biological interactions, as is frequently documented in benthic communities. It is unlikely that accurate prediction of the response of fish populations to perturbations such as ENSOs and regime shifts will ever be possible without a better understanding of community dynamics. However, it is clear that El Niño have strong effects that translate up the food chain and cause die offs in the higher trophic levels such as sea birds and mammals (Limberger 1990, Ainley et al. 1995, Ainley et al. 1996, Veit et al. 1996).

The clearest picture of the long term correlation of fish populations to natural variability comes from the paleosediment records of fish scales from sardine, Sardinops sagax, and anchovy, Engraulis mordax, from anoxic basins in the southern California bight (Baumgartner et al. 1992). These show alternating periods of dominance by each of these two species with time scales of about 60 years. Fig. 13 (Baumgartner et al. 1992) shows the reconstructed sardine populations over the past 1,500 years. Reconstructing population levels from scale abundance involves a number of assumptions, but the natural fluctuation is a robust signal (before human intervention) with time scales of 50-60 years. These data show the recent decline in population in the middle of the
1900 s, after remaining relatively high or moderate (2-4 mmt) over the previous 150 years. Fig. 14 shows the sardine and anchovy catch in the California and Peru-Chile (Humboldt) current systems during this century. The initial increases represent the spin-up of fishery activity; after that, catch serves as an indicator of population size. Note the different in scales for the two hemispheres. These data show the crash of the California sardine in the mid-1940s and the Peruvian anchovy in the early 1970s. Anchovies replaced the sardines off California, while sardines replaced the anchovy off Peru and Chile. Recently, sardines have returned to the California current and anchovies to the PeruChile current, as discussed below (Chavez et al. 2003).

Comparisons of small pelagic populations in the north and south Pacific basin (including the Japanese sardine) led a number of fisheries biologists to look for basin-scale environmental factors that could cause synchronous changes in the populations. Considering the recent several decades, a shift in environmental conditions in the north Pacific in the mid-1970s has been well documented, with effects on many physical and biological variables. Comparison SST fields from the entire north Pacific for the 10-year period prior to 1977 to the 10 year period after 1976 showed a general warming of the region next to western North America (from California to Alaska) and a cooling of the central Pacific around 1977 in both boreal winter and summer (Parrish 1997). Winds increased in mixing power during winter after 1976 and also formed a stronger counterclockwise gyre, conducive to upwelling in the central Pacific and eastward movement of warmer surface water in the

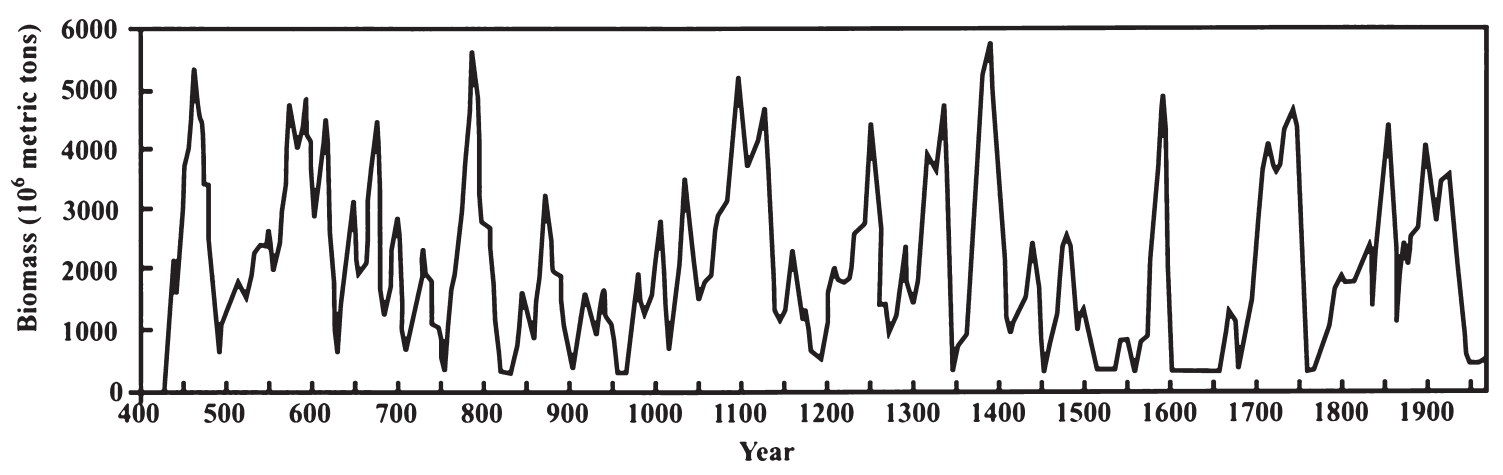

Fig. 13: Time series of reconstructed biomasses (5 years samples) of the California sardine from scale deposition rates obtained from the varved sediments (AD 440-1970) of the Santa Barbara Basin off southern California (after Baumgartner et al. 1992)

Series de tiempo de biomasas reconstruidas (muestras de 5 años) para la sardina de California en base a la tasa de depositación de escamas de los sedimentos (AD 440-1970) de la cuenca de Santa Barbara, California del sur (en base a Baumgartner et al. 1992). 

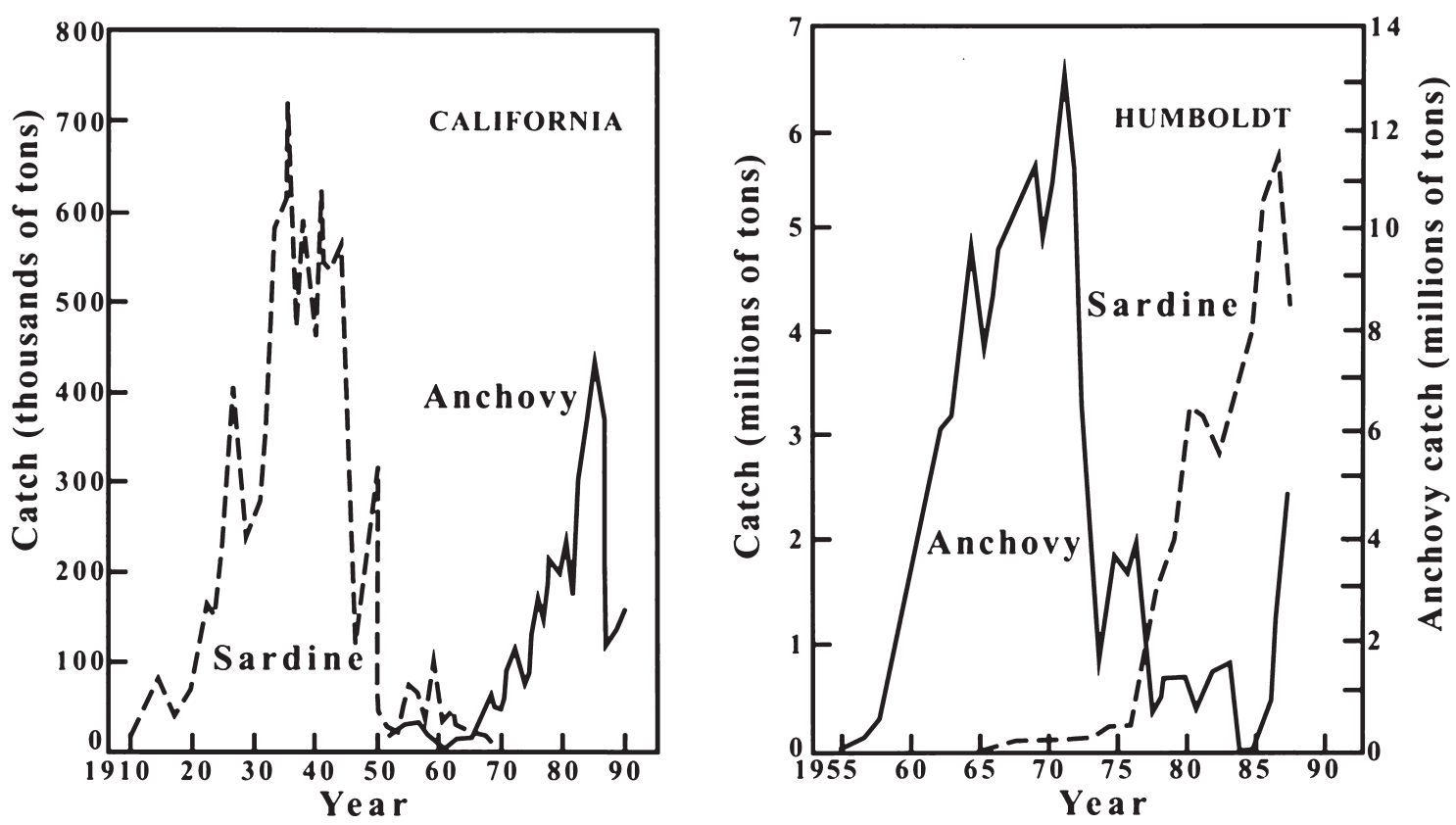

Fig. 14: Time series of catches for the sardines and anchovies in the California current compared to the Peru-Chile (Humboldt) current. Note differences in the vertical scales and that catches off South America are orders of magnitudes greater than off North America (data from Schwartzlose et al. 1999).

Series de tiempo de capturas para la sardina y anchovetas en la corriente de California comparadas con la corriente de Perú-Chile (Humboldt). Nótense las diferencias en las escalas verticales y que las capturas en América del Sur son órdenes de magnitud mayores que en América del Norte (datos de Schwartzlose et al. 1999).

eastern Pacific. These winds are related to a strengthening of the Aleutian low following 1976. Thus, changes in the atmospheric forcing favored the warmer surface waters and deeper mixed layers along the eastern Pacific and upwelling and mixing of colder water in the central North Pacific. Miller (1996) reproduced these conditions in a basin-scale ocean model.

Coincident with these physical changes, Brodeur et al. (1996) found a general increase in zooplankton populations in late-spring and early summer in the central sub-arctic domain. Venrick et al. (1987) showed that changes in phytoplankton concentrations also occurred in the mid-Pacific north of Hawaii around 1977. Polovina et al. (1995) used a mixed layer model, coupled with an ecosystem model, to produce a 30-80 \% deepening of the boreal winter and spring mixed layer in the Subtropical Domain and central Transition Zone and a $20-30 \%$ shoaling of the mixed layer in the northern Subarctic Domain. Based on modeling of phytoplankton response to these changes, Polovina et al. (1995) speculated that these physical conditions would increase primary and secondary production in the northern Subtropical and northern (central) Subarctic domains and decrease them in the transition zone, which flows eastward and equatorward on the offshore side of the
California current, then enters the southern California bight. This connection between decreased zooplankton production in the Transition Zone and the bight would provide a possible explanation to the greatly decreased zooplankton populations observed in the bight by Roemmich \& McGowan (1995). Roemmich \& McGowan (1995) attribute the change to decreased nutrient upwelling due to increased temperatures and mixed layer depths as a result of global warming. However, nutrient and chlorophyll concentrations (representing phytoplankton abundance) off southern California have not shown a decline during the past 15 years, during which time zooplankton volumes continued to decrease (Hayward et al. 1996). This suggests that processes other than local bottom-up dynamics are responsible for the long-term decrease in zooplankton biomass (McGowan et al. 1996).

Mantua et al. (1997) have looked at climate data from a longer period covering 1900- 1996. They find that the change in conditions in 1977 is just one phase shift of a longer cycle. Figure 15 shows their time series of a PDO index (Mantua et al. 1997). The PDO is constructed from the first empirical orthogonal function (EOF) of SST north of $20 \mathrm{~N}$ (the first EOF is essentially the first principal component of the gridded SST time 

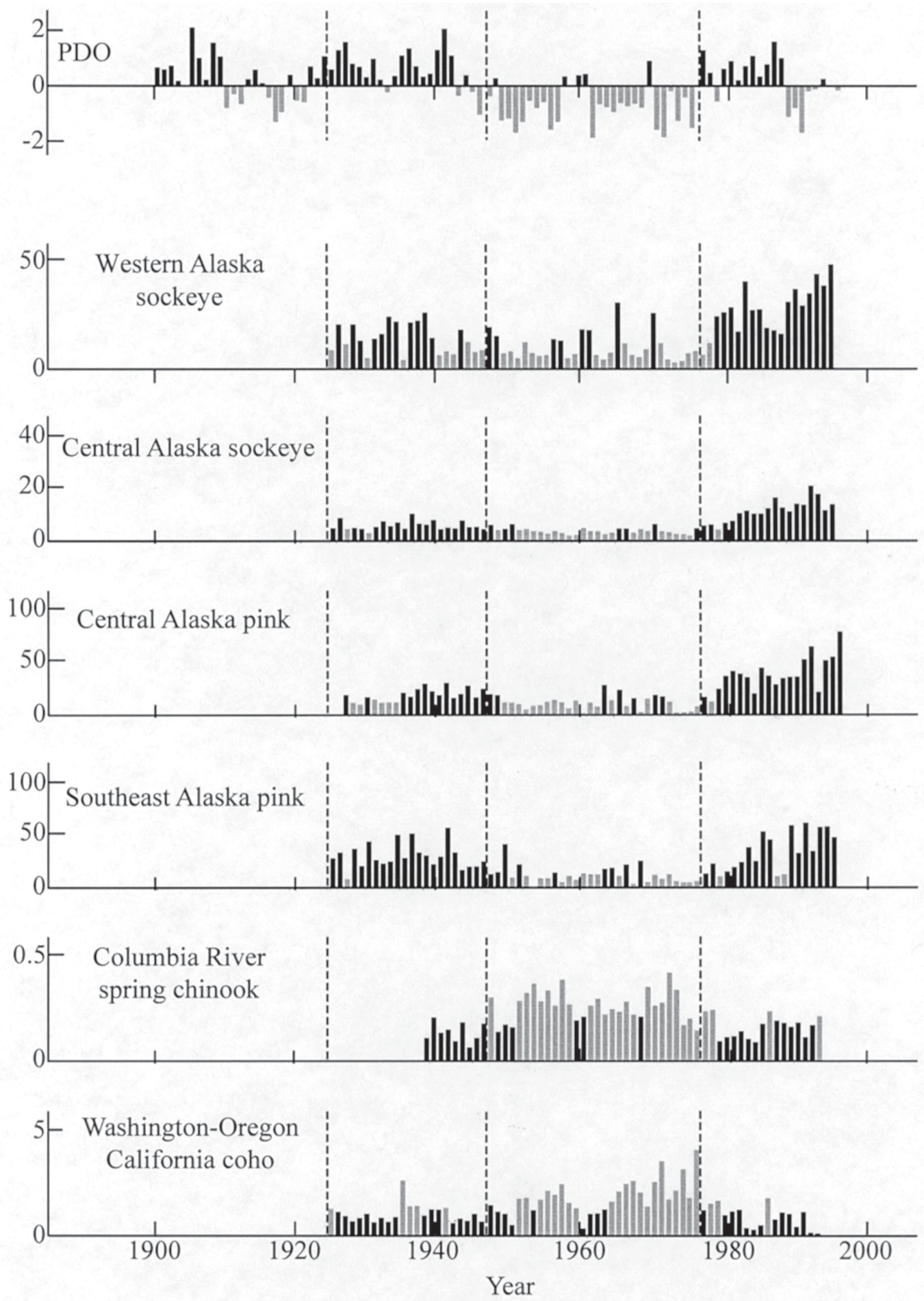

Fig. 15: Selected Pacific salmon catch records with PDO signatures. For Alaska catches, solid bars indicate values that are greater than the long term median. The shading convention is reversed for WOC coho and Columbia River spring chinook. Vertical dotted lines indicate PDO reversal times in 1925, 1947, and 1977. The PDO index is shown in the top panel (after Mantua et al. 1997).

Registros seleccionados de capturas del salmón del Pacífico con señales de la ODP. Para las capturas en Alaska, las barras sólidas indican valores que son mayores que la media de largo plazo. El sombreamiento es revertido para WOC los salmones coho y chinook del río Columbia. Las líneas verticales punteadas indican los tiempos de reversión en la ODP en 1925, 1947, y 1977. El índice ODP se muestra en el panel superior (en base a Mantua et al. 1997). 
series) (Preisendorfer 1988). The spatial pattern associated with this EOF is similar to the pattern described above: warm water along the eastern boundary of the north Pacific and cold water in the central gyre. The yearly value of the PDO is the average of the time series of this EOF during November-March. It thus represents the dominant SST pattern during the cold period of the year (when surface waters are well mixed and not disguised by shallow warm layers). Mantua et al. (1997) use intervention analysis to argue for rapid changes in conditions in 1925, 1947 and 1977. When SST and atmospheric pressure from the entire Pacific basin are regressed against the PDO, the SST pattern described above is recovered, with a connection between the warm northeast Pacific, a warm band along the equator, and another warm region in the southeast Pacific next to South America, linking the environmental variability in the two Pacific eastern boundary currents. The atmospheric pressure pattern associated with the PDO consists primarily of lower pressures in the Alaska Gyre (a deeper Aleutian Low). When the basinwide SST and atmospheric pressure signals are regressed against a cold tongue index (CTI, a measure of the mean SST in the equatorial Pacific), a similar pattern emerges, even though the CTI has ENSO time scales of 3-7 years and the PDO has time scales of 30-50 years. The relationship between the interannual and interdecadal changes is unknown and a subject of active research.

The PDO is correlated with a number of other variables. We refer to periods of positive PDO as "warm periods," focusing on the warm eastern boundaries of the north (and south) Pacific when the index is positive. Mantua et al. (1997) show that, during warm periods, air temperature is also warmer around the eastern basin (from southern California to Alaska) and precipitation is greater in the Alaska Gyre and less between northern California and British Columbia. The precipitation is reflected in greater stream flow in the Alaskan Gyre and lower stream flow in the Pacific northwest.

Perhaps more striking than the correlation of physical factors with the PDO is the correspondence of warm phases of the PDO with higher salmon catch in the Alaskan Gyre, with lower salmon catch in the Pacific Northwest, and the seeming coincidence with increased survival of sardine in the California current. In Fig. 15 (Mantua et al. 1997) along with the PDO are plotted fish catch of four Alaska salmon stocks and two Pacific Northwest salmon stocks. Intervention analysis was used to fit step changes to the PDO and the salmon stocks. The fit to the PDO gives best results for the dates indicated with vertical dotted line in Fig. 15. The fits for the Alaska sockeye, Onchorhynchus nerka, stocks give a step change 2-3 years after the PDO change, while the fits for the Alaska pink, $O$. gorbuscha, give a step change one year after the PDO. Since pink salmon spend little time in the fresh water and only a year at sea, the difference in timing is consistent with a correlation between survival and conditions during the early life history. Pearcy (1992) used data from the Pacific Northwest to suggest that the critical period in the oceanic phase is during the first weeks or months after juveniles enter the ocean from fresh water. The lags of the intervention analysis can be interpreted to support this hypothesis. Off the Pacific Northwest, Pearcy (1992) suggests that predation by warm-water fish (mackerel, hake) decreases survival of the juveniles during warm periods, a hypothesis in need of testing. Mechanisms responsible for increases in the salmon populations in the Gulf of Alaska during the warm water years are not known. The size of caught salmon in the Gulf of Alaska has declined; leading to the hypothesis that they have reached or exceeded the carrying capacity of their environment due to unusually low mortality levels in their earlier stages of life history and are now food limited (United States GLOBEC 1996).

Gargett (1997), suggests a mechanism whereby the productivity in the gulf of Alaska and California current systems may be coupled. Using the concept of the "optimal environmental window" she presents the idea that if the stability of the water column in the entire eastern coastal north Pacific increases, this will favor higher phytoplankton growth rates in the Gulf of Alaska but lower growth rates in the California current system. Conversely, decreases in the stability everywhere will favor high phytoplankton growth rates in the California current but lower rates in the Gulf of Alaska. Differences in resource limitation within the two current systems underlie the difference. Gulf of Alaska phytoplankton stocks are more light limited, whereas California current stocks are more nutrient limited. She suggests that if stability of the water column varies in phase over the entire eastern coastal North Pacific then secondary production and salmon survival will vary out of phase.

Considering that the simple patterns shown in Fig. 14 and 15 for sardine, anchovy and salmon suggest a connection between basinscale conditions and the fish populations during this period, one might ask why the sardine population did not rebound off California in the mid-1970s. Although sardine populations reached low values in 1960s and 1970s, enough remained to estimate the rates of larval 
survival. The California Cooperative Oceanic Fisheries Investigations estimates of those survival rates have been used to model what the biomass of a sardine population would have been if fishing had been eliminated (Fig. 16). Whereas the observed biomass reached lows of around $10,000 \mathrm{mmt}$, the minimum in biomass that would have been reached if fishing had been halted in 1950 would have been around $0.5 \mathrm{mmt}$. Larval survival rates improved in the second half of the 1970s, after the switch to the warm conditions and would have resulted in a biomass of over $1.0 \mathrm{mmt}$ early in the 1980's. Instead, the population took an extra decade or longer to recover, reaching a biomass of 1.0 mmt by the early or mid-1990s.

Using Fig. 16 and the clarity of hindsight, the consequences of continuing to fish the sardine to levels below approximately $0.5 \mathrm{mmt}$ can be seen. Assuming that harvest was stopped at $0.5 \mathrm{mmt}$ on the observed biomass curve and remained near $0.5 \mathrm{mmt}$, the biomass would have been roughly equivalent to the unfished population at $0.5 \mathrm{mmt}$ in the late $1970 \mathrm{~s}$. If fishing were resumed at $1.0 \mathrm{mmt}$, a much greater harvest would have been available at the beginning of the next cycle than that taken at the end of the previous cycle. By harvesting the last 2-3 mmt over the period 1947-1952, this future gain was lost. This is perhaps one of the clearest examples of the way in which human activity (harvesting) may interact with and disrupt natural temporal variations in marine populations. Although even this hypothesized scenario is not certain, the availability of an historical proxy record of population variations (from the fish scale records) gives a rare estimate of the natural variability, prior to human intervention.

In the case of the salmon, this separation of natural and anthropogenic causes of population variability is not as clear. Harvests of salmon began before 1900 in the Pacific northwest, and we have no proxy for the natural variability before human impacts. Furthermore, the two most recent dates (1947 and 1977) for a change in the PDO are also dates of significant changes in fishing and other human activities. PostWorld War II spin-ups in fishing occurred during the late 1940s. A period of dam building in the Pacific northwest reached a culmination in the mid-1970s that resulted in over 100 dams on the Columbia River system (NRC 1996). On top of this, the PDO correlations with streamflow indicates that natural river conditions deteriorated after 1977 in the Pacific northwest and improved in the streams flowing into the Alaska Gyre. In addition, logging in the 1980s in this area reached record levels and resulted in the degradation of stream conditions necessary for successful spawning of salmon. Grazing on public lands increased at the same time to similar effect. During the entire time, fishing pressure increased on those salmon populations that persisted. Mantua et al. (1997) argue that the increases in the populations of Alaska stocks, especially the two pink salmon stocks (which spend little time in fresh water), after 1977 shows the clear connection of ocean conditions and fish stocks. They suggest that human interactions make the records of the Pacific northwest stocks less clear, but that the

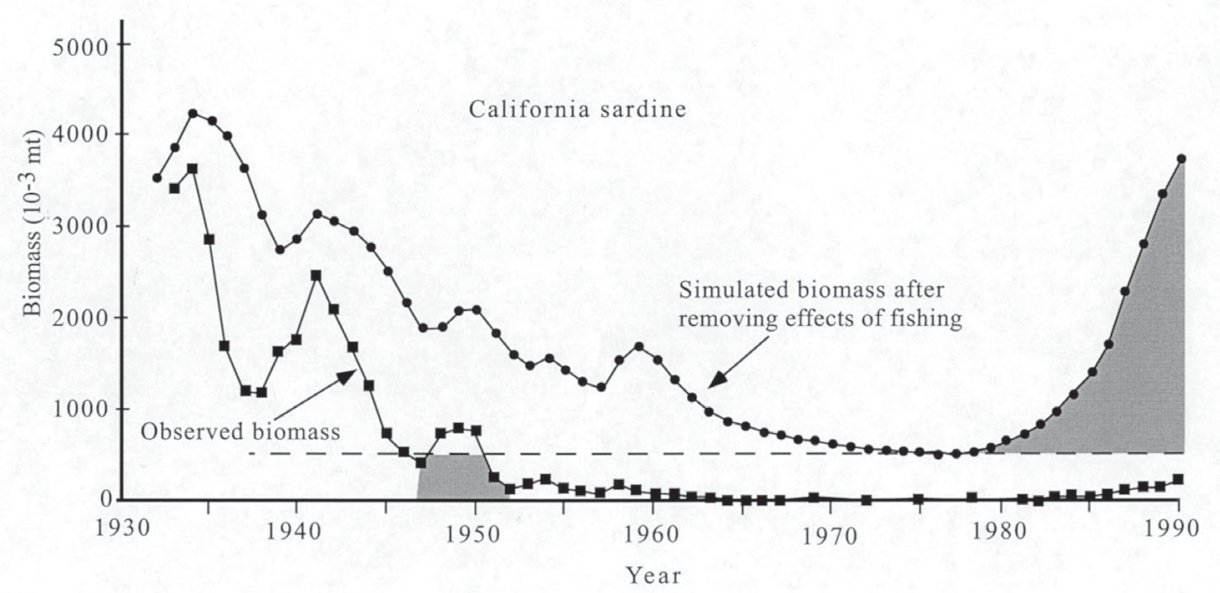

Fig. 16: Time series of sardine biomass (1932-1990) obtained from observation of the actual population and from a model simulation to remove the effects of fishing (see text).

Serie de tiempo de la biomasa de sardina (1932-1990) obtenida en base a observaciones de las poblaciones actuales y a partir de un modelo de simulación para remover el efecto de la pesquería (ver texto). 
natural cycles are still present. Assuming that the PDO and Alaska stocks give the clear picture and that oceanic conditions became worse for the Pacific northwest stocks (due to increased predation or other factors), the lesson is similar to the sardine. During a period of naturally low salmon population levels, human activity drove those populations to unnaturally low levels. In some cases, stocks became extinct and more are in danger of following the same path.

In the Pacific northwest, the regime shift of 1976-1977 is associated with changes in the migration patterns and abundance of other fish species. The population of Pacific hake, Merluccius productus, found off Oregon, Washington and British Columbia in summer may have modified its spawning behavior. Until recently the stock migrated to the southern California bight to spawn during boreal winter. Now, juvenile hake are caught off Oregon by the shrimp trawl fishery suggesting that hake now spawn much further north.

There appear to be orderly changes in dominance among coastal pelagic fishes (McCall 1996). Coastal pelagic fish abundances since 1930 indicate an orderly sequence of four or five dominant species with cycles that are very similar to those observed in Japan-peaks in abundance of mackerel (Scomber japonicus) are followed by sardines, then bonito (Sarda chiliensis) and anchovies, with each peak separated in time by roughly 10 years. As the abundance of the coastal pelagic species increases in concert with the warming of the California current, the distributions shift northward. Pacific mackerel are now common in the northern California current, in Canadian waters and into the Gulf of Alaska, and the sardine are conspicuous in waters of Oregon, Washington and off Vancouver Island, and are known to be spawning off the coast of Oregon (Bently et al. 1996).

Another influence on the abundance of fish populations may be the Metonic (18.6-year) cycle, which has been shown to correlate with larval abundance of the Pacific halibut, Hippoglossus stenolepis, (Fig. 17, Parker et al. 1995). The importance of the Metonic cycle or its possible mechanism in driving halibut or other oceanic fish populations is unknown, but it should be investigated as to whether the observed patterns are spurious correlations or indicative of a physical forcing.

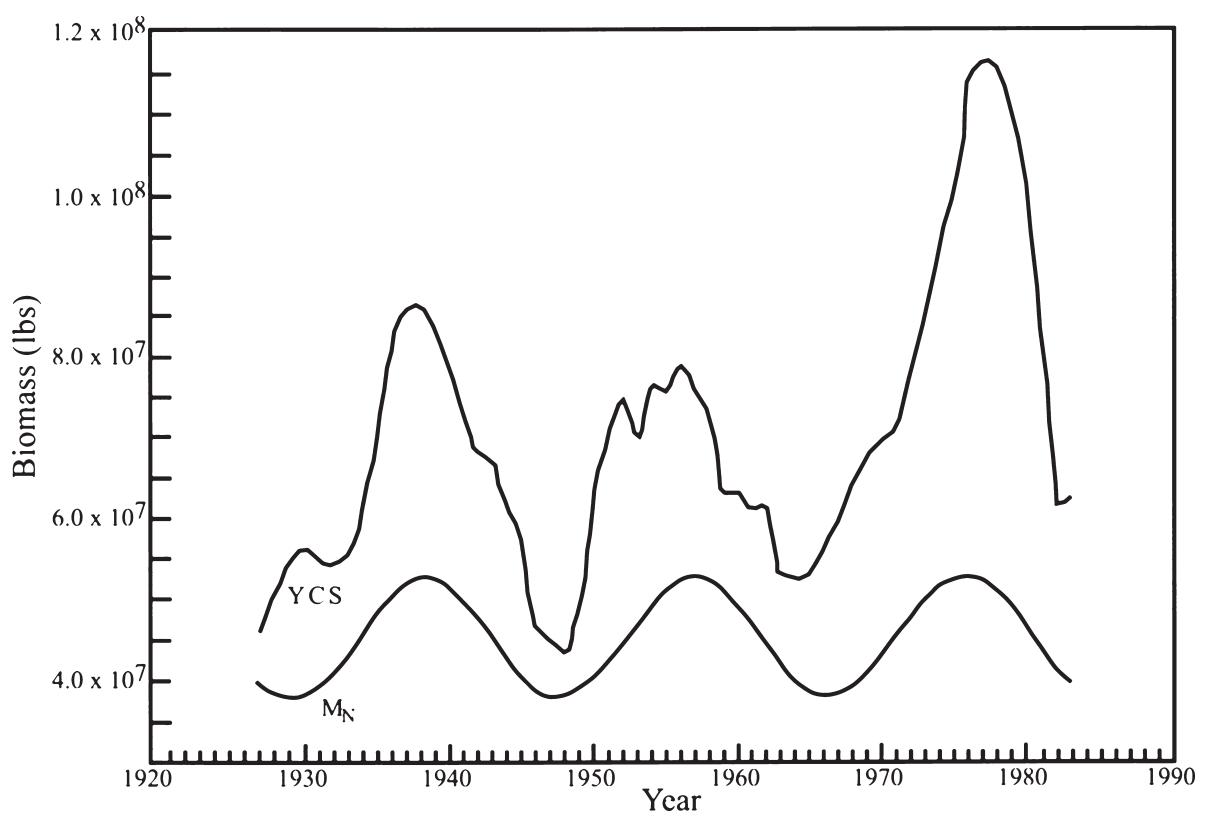

Fig. 17: The Pacific halibut recruitment biomass record, 1927-1983 (YCS = year class strength), with the 'best fit' lagged 18.6 year lunar nodal tide signal (Mn). The abundance series has been corrected for regional catchabilities, gear selectivities, weights-at-age, and incidental bycatch, and smoothed with three years moving average (after Parker et al. 1995).

Registro de la biomasa de reclutamiento para el lenguado del Pacífico, 1927-83 (YCS = importancia de la clase de edad) con el mejor ajuste retrasado en 18.6 años con respecto a la señal lunar nodal (Mn). La serie de abundancia ha sido corregida por la habilidad de capturas regionales, selectividad del arte de pesca, peso a la edad de captura, capturas incidentales, y suavizada con un promedio móvil de 3 años (en base a Parker et al. 1995). 


\section{Coho salmon management as an example}

Coho salmon reside in the ocean during approximately half of their life. Adults migrate into their natal streams (or to their natal hatchery) in fall and lay eggs, which in turn produce offspring that spend one year in fresh water before migrating to sea as $1+$ year old fish. The fish then spend 1.5 years in the ocean before returning to freshwater. Most of the mortality during the oceanic phase is thought to take place during the first 6-8 weeks at sea (Pearcy 1992).

Reliable estimates of the abundance of Oregon-California coho salmon are available only from 1970 until present. Those data show that abundances during the 1970s ranged between 2 and 4 million fish. Abundances reached a peak of 4.5 million fish in 1976 and have declined ever since. Two periods of rapid decline occurred: between 1976 and 1977, numbers declined three-fold, from 4.5 to 1.5 million, and between 1991 and 1992, numbers declined four-fold, from 2 million to 500,000 fish. The rapid change in numbers in 1976 is similar in scope to what was noted above for Alaska sockeye and pink salmon (Francis \& Hare 1994). Abundances of coho declined in 1976 in part because survival declined (Fig. 18). The survival time series shows two dramatic drops: for coho that entered the ocean in spring 1976 and for those entering in 1991. Over the first period of decline, harvest levels of coho remained high through the early 1980s (Fig. 19). Thus, given that the fish were harvested at very high rates, the changes in abundance in the early 1980 s were caused primarily by both fishing and climate driven changes in ocean conditions. This is not to say that watershed degradation and hydroelectric dams were not also contributing factors to declines. For the 1990s, a different set of circumstances operated.

Wild coho salmon stocks in central California, northern California/ southern Oregon, and coastal Oregon are listed as threatened species under the ESA, other evolutionarily significant units are candidates for listing as threatened (1995, 1996, USFWS 1997, USNMFS 1998). The 1983 El Niño event awakened managers to the fact that the coho stocks were in trouble. Due to over fishing and poor ocean conditions, coho abundances had declined greatly as compared to the 1960s and 1970s. Managers implemented regulations at the start of the 1984 fishing season that led to reduced catches, through a shortening of the length of the fishing season. In addition, harvest quotas were established. Catches were carefully monitored and the fishery terminated when quotas were reached. The stocks began to rebound in 1986 suggesting that controls on harvest were working. However, the "recovery" only lasted for about five years. Between 1991 and 1993 exploitation rates were reduced greatly and were reduced further in 1994 and 1995 but the population did not respond positively. Survival dropped below $1 \%$ in 1991, a level which could not tolerate any fishing whatsoever. The abundance of wild coastal coho may be less than 500,000 animals, although estimates of population size remain controversial. The cause of this recent catastrophic decline may be due to the extended El Niño-like conditions that have persisted off Oregon since 1992 and the severe El Niño of 1997-1998. Thus, in the present situation, the decline in abundance has been due to a combination of poor survival and poor ocean conditions as opposed to the case in 1976, when numbers declined as a result of over fishing along with an as yet unquantified change in ocean conditions.

It is now over 20 years since the regime shift of 1976-1977 and there are as yet no explanations that account for the response of the ecosystem to the event. A large number of papers have been published which document physical and biological changes and show correlations among changes in biomass, migration patterns or distribution of resource species with climate, atmospheric or physical oceanographic variables. Few published papers have suggested mechanisms; few have demonstrated how changes in physical, trophic factors or anthropogenic factors might lead to the observed changes in the density or productivity of a given resource. Our ignorance may remain if the suggestions of Ware (1995) and McCall (1996) are true - they argue that we may now be experiencing another regime shift. The most extreme ENSO event of this century occurred in 1997-1998, with dramatic impacts worldwide. Almost uninterrupted El Niño-like conditions have occurred off Oregon since 1992, which bodes poorly for coho. The scientific research community must educate the public about how climate variability and climate change affects resources. Managers of living marine resources at the federal, state and local levels need to be informed of recurring regime shifts because most management plans incorrectly assume the ocean does not contribute significant variability to spawning stock biomass. A better understanding of how the ecosystem as a whole responds to regime shifts may be the key to understanding stock responses. 


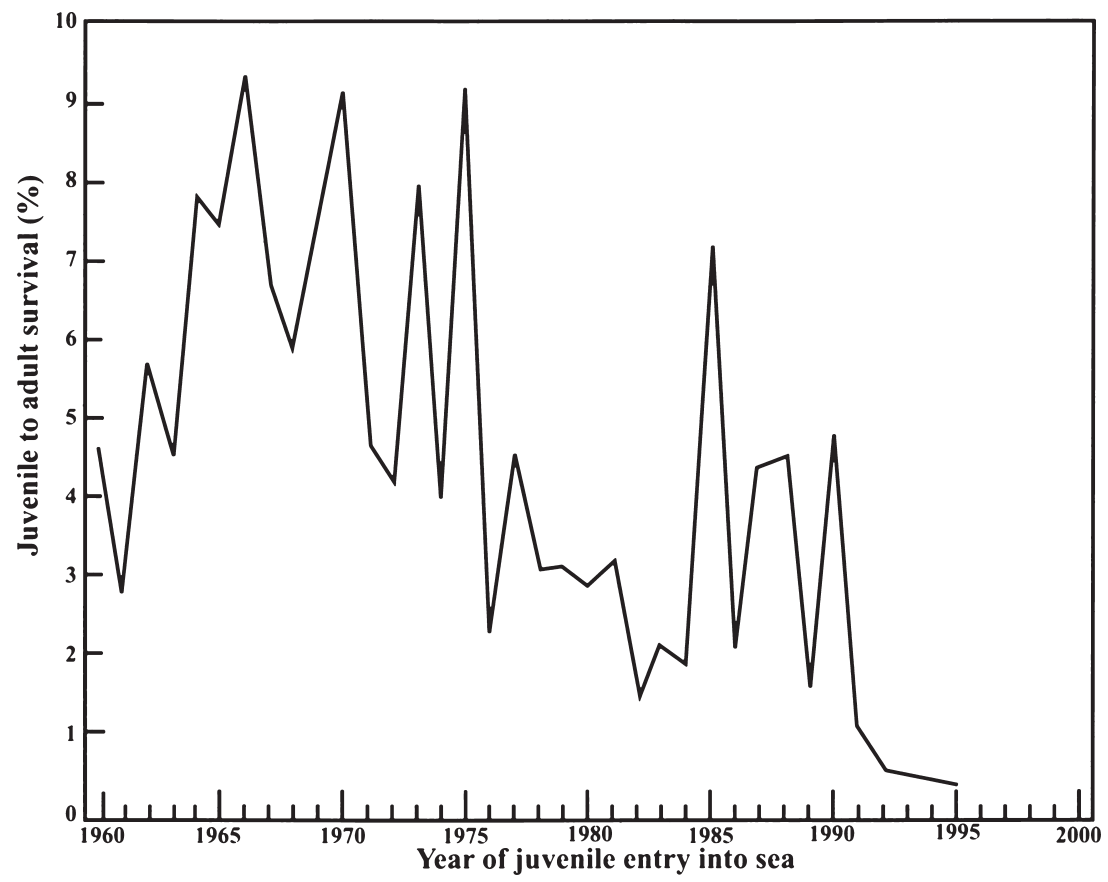

Fig. 18: Time series showing the year that hatchery-raised juvenile coho enter into the North Pacific Ocean versus the percent of those juveniles surviving to adulthood (data from Pacific Fisheries Management Council 2001)

Serie de tiempo que muestra el año en que los juveniles de salmones coho criados en jaulas entran al Océano Pacífico del norte versus el porcentaje de juveniles que sobreviven hasta la adultez (datos del Pacific Fisheries Management Council 2001).

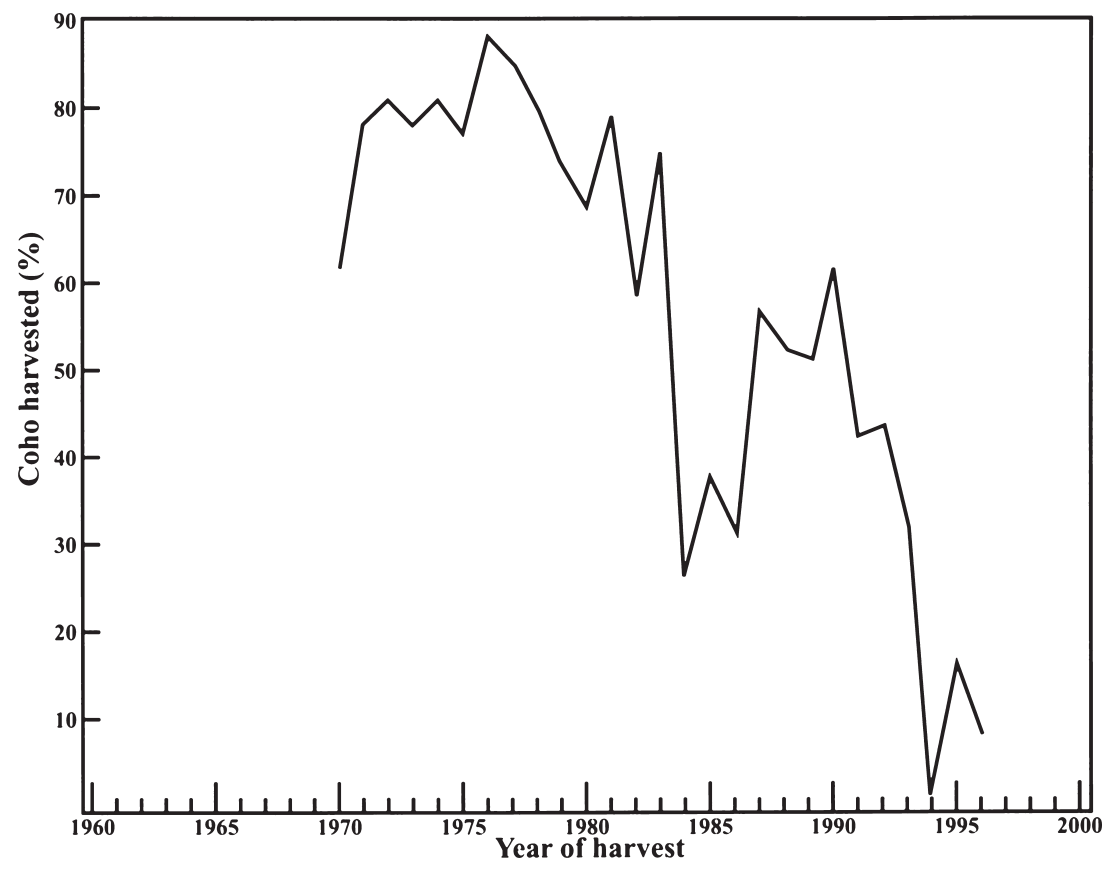

Fig. 19: Percent of California coho harvested versus time (data from Pacific Fisheries Management Council 2001).

Porcentaje de salmones coho de California cosechados versus tiempo (datos del Pacific Fisheries Management Council 2001). 


\section{TOWARD AN ECO-OCEANOGRAPHIC INTEGRATION}

Evidence supports the existence of natural fluctuations in basin-scale physical environmental conditions that include atmospheric pressure systems, wind forcing, precipitation, surface temperature and mixed layer depth. In the oceanic ecosystems, changes in nutrient fluxes, phytoplankton and zooplankton concentrations are linked to the physical changes. However, communities where biotic interactions have been well studied, such as the rocky shore, and where both oceanographic and biotic factors have been studied, such as kelp forests, demonstrate that community wide effects of physical parameters are always mediated by biotic interactions. For example, the oceanographic effects of El Niño underlie dramatic losses in kelp biomass in North America. One could correctly correlate the biomass loss with physical factors such as nutrient depletion and storms and incorrectly conclude that nutrient depletion and storms directly accounted for the total kelp die off. In doing so the important role that urchins and sea otters play in kelp forest dynamics would be completely overlooked. Conversely, without knowledge of oceanographic conditions, the framework that underlies biotic factors, such as the loss of drift kelp forcing urchins to graze on standing kelp, would be missed. Similarly, in the 1960s, the collapse of the California sardine fishery was widely believed to be due solely to overfishing. The evidence presented above suggests that it was due to continued fishing at previous level while the population was in a period of natural decline.

The dominant time scales of changes in many marine resources tends to be several decades, which have historically been attributed to human exploitation alone. As described above, there is growing evidence of natural variability of the environment and populations on these time scales (PDO, Metonic cycle, ENSOs), although it is usually difficult to separate natural variability from human influences. This raises the possibility of interactions between human actions and these longer, and consequently harder to recognize, natural cycles. Failure to understand and detect these cycles and modify harvesting pressures may result in substantial losses of harvestable marine populations (as in the case of the California sardine), which would have rebounded if they had been allowed to remain at viable levels during their natural low phases.

Whatever lies ahead, it is now well established that the productivity of eastern boundary currents oscillates at frequencies of 20-60 years and is linked to decadal scale variability in the atmospheric circulation. These low frequency oscillations in productivity explain the spectacular collapse of the Monterey sardine in the late 1940s (and their recovery in the 1990s), the collapse of the Peruvian anchovy in the 1960s (and their "miraculous" recovery in the 1990s), and may partially explain the demise of the coho salmon in the Pacific northwest. Such collapses/ recoveries of commercially valuable fish stocks seem to be inevitable consequences of our inadequate understanding of these ecosystems. In order to reduce the impact of boom-bust cycles on social structure and economies of local communities, we need improved resource management models based on understanding of atmospheric and oceanic factors that underlie these oscillations, improved capability to predict these regime shifts, and a better understanding of community dynamics. It is doubtful that adverse fluctuations in the stocks can be avoided entirely, but if management were armed with the above knowledge and acted appropriately, it should be possible to reduce the severity and duration of the downturns and their resultant economic and social hardships.

Clearly, to understand and manage benthic and oceanic ecosystems, an integration of oceanography and ecology is required. This includes an understanding of both small-scale biotic interactions and large-scale climactic fluctuations. Unfortunately progress has been thwarted by a historical separation of the disciplines intellectually and in the case of nearshore benthic ecology versus open ocean oceanography, a physical gap as well. Logistic factors, such as the difficulty of investigating biotic interactions in the open ocean have also impeded progress. However, integration is possible with collaboration between ecologists and oceanographers, and a better understanding of how marine communities respond to largescale oceanographic fluctuations will result.

\section{ACKNOWLEDGEMENTS}

The authors wish to thank Bruce Menge, Jange Lubchenco and the members of their laboratory for their input on the manuscript. Writing of his manuscript was supported in part by the Andrew J. Mellon Foundation and the David and Lucile Packard Foundation. This is contribution number 28 of the Partnership for Interdisciplinary Studies of Coastal Oceans (PISCO): A LongTerm Ecological Consortium funded by the David and Lucile Packard Foundation. 


\section{LITERATURE CITED}

AINLEY DG, WJ SYDEMAN \& J NORTON (1995) Upper trophic level predators indicate interannual negative and positive anomalies in the California current food web. Marine Ecology Progress Series 118: 69-79.

AINLEY DG, LB SPEAR \& SG ALLEN (1996) Variation in the diet of Cassin's auklet reveals spatial, seasonal, and decadal occurrence patterns of Euphausiids off California, USA. Marine Ecology Progress Series, 137: 1-10.

ALLISON GW, J LUBCHENCO \& MH CARR (1998) Marine reserves are necessary but not sufficient for marine conservation. Ecological Applications 8: S79-S92.

ARNTZ WE \& J TARAZONA (1990) Effects of El Niño 1982-1983 on benthos, fish and fisheries off the South American Pacific coast. In: Glynn PW (ed) Global ecological consequences of the 1982-1983 El Niño Southern Oscillation (1989): 323-360. Elsevier, Amsterdam, The Netherlands.

BAKUN A (1990) Global climate change and the intensification of coastal ocean upwelling. Science 247: 198-201

BARBER RT \& FP CHÁVEZ (1983) Biological consequences of El Niño. Science 222: 1203-1210.

BARRY JP, CH BAXTER, RD SAGARIN \& SE GILMAN (1995) Climate-related, long-term faunal changes in a California rocky intertidal community. Science 267(5198): 672-675.

BARTH JA \& RL SMITH (1998) Separation of a coastal upwelling jet at Cape Blanco, Oregon, USA. South African Journal of Marine Science 19: 5-14.

BARTH JA, SD PIERCE \& RL SMITH (2000) A separating coastal upwelling jet at Cape Blanco, Oregon, and its connection to the California current system. Deep-Sea Research Part II 47: 783-810.

BAUMGARTNER TR, A SOUTAR \& V FERREIRABARTRINA (1992) Reconstruction of the history of pacific sardine and northern anchovy populations over the past two millennia from sediments of the Santa Barbara Basin, California. California Cooperative Oceanic Fisheries Investigations Reports 33: 24-40.

BEAMISH RJ (ed) (1995). Climate change and northern fish populations. Canadian Special Publications in Fisheries and Aquatic Sciences. NRC Press, Ottawa, Canada. 739 pp.

BEATLY T (1991) Protecting biodiversity in coastal environments: introduction and overview. Coastal Management 19:1-19.

BENTLY PJ, RJ EMMETT, NCH LO \& HG MOSER (1996) Egg production of pacific sardine (Sardinops sagax) off Oregon in 1994. CoICOFI Repport.

BLANCO JL, AC THOMAS, ME CARR \& PT STRUB (2001) Seasonal climatology of hydrographic conditions in the upwelling region off northern Chile. Journal of Geophysical Research-Oceans 106: 11451-11467.

BLANCO JL, ME CARR, AC THOMAS \& PT STRUB (2002) Hydrographic conditions off northern Chile during the 1996-1998 La Niña and El Niño events. Journal of Geophysical Research-Oceans: 107.

BODKIN JL (1989) Effects of kelp forest removal on associated fish assemblages in central California. Journal of Experimental Marine Biology and Ecology 117: 227-238.

BOTSFORD LW, LE MORGAN, DR LOCKWOOD \& JE WILEN (1999) Marine reserves and management of the northern California red sea urchin fishery. California Cooperative Oceanic Fisheries Investigations Reports 40: 87-93.

BRANDHORST W (1971) Condiciones oceanográficas estivales frente a la costa de Chile. Revista de Biología Marina, Valparaíso (Chile) 14: 45-84.

BREEN PA, TA CARSON, JB FOSTER \& EA STEWART (1982) Changes in subtidal community structure associated with British Columbia sea otter transplants. Marine Ecology Progress Series 7: 12-20.

BRINK KH \& TJ COWLES (1991) The coastal transition zone program. Journal of Geophysical Research 96: 14637-14647.

BRINK KH, D HALPERN, A HUYER \& RL SMITH (1983) The physical environment of the Peruvian upwelling system. Progress in Oceanography 12: 285-306.

BRINK KH, BH JONES, JCV LEER, CNK MOOERS, DW STUART, MR STEVENSON, RC DUGDALE \& GW HEBURN (1981) Physical and biological structure and variability in an upwelling center off Peru near $15^{\circ} \mathrm{S}$ during March 1977. In: Richards FA (ed) Coastal upwelling: 473-495. American Geophysical Union, Washington, District of Columbia, USA.

BRODEUR RD, BW FROST, SR HARE, RC FRANCIS \& WJ INGRAHAM JR. (1996) Interannual variations in zooplankton biomass in the gulf of Alaska, and covariation with California current zooplankton biomass. California Cooperative Oceanic Fisheries Investigations Reports 37: 80-99.

BROITMAN BR, SA NAVARRETE, F SMITH \& SD GAINES (2001) Geographic variation of southeastern Pacific intertidal communities. Marine Ecology Progress Series 224: 21-34.

CANCINO JM \& JC CASTILLA (1988) Emersion behaviour and foraging ecology of the common Chilean clingfish Sicyases sanguineus (Pisces: Gobiesocidae). Journal of Natural History 22: 249-261.

CASTILLA JC (1988) Earthquake-caused coastal uplift and its effects on rocky intertidal kelp communities. Science 242: 440-443.

CASTILLA JC (1994) The Chilean small-scale benthic shellfisheries and the institutionalization of new management practices. Ecology International Bulletin 21: 47-63.

CASTILLA JC (1999) Coastal marine communities: trends and perspectives from human-exclusion experiments. Trends in Ecology and Evolution 14: 280-283.

CASTILLA JC (2000) Roles of experimental marine ecology in coastal management and conservation. Journal of Experimental Marine Biology and Ecology 250: 3-21.

CASTILLA JC \& RT PAINE (1987) Predation and community organization on eastern Pacific, temperate zone, rocky intertidal shores. Revista Chilena de Historia Natural 60: 131-151.

CASTILLA JC \& PA CAMUS (1992) The Humboldt-El Niño scenario: coastal benthic resources and anthropogenic influences, with particular reference to the 1982/1983 ENSO. In: Payne AIL, KH Brink, KH Mann \& R Hilbom (eds) Benguela Trophic Functioning: 703-712. South African Journal of Marine Science.

CASTILLA JC \& M FERNÁNDEZ (1998) Small-scale benthic fisheries in Chile: on co-management and sustainable use of benthic invertebrates. Ecological Applications 8: S124-S132.

CASTILLA JC \& O DEFEO (2001) Latin American benthic shellfisheries: emphasis on co-management 
and experimental practices. Reviews in Fish Biology and Fisheries 11: 1-30.

CASTILLA JC, SA NAVARRETE \& J LUBCHENCO (1993) Southeastern Pacific coastal environments: main features, large-scale perturbations, and global climate change. In: Mooney HA, ER Fuentes \& BI Kronberg (eds) Earth system responses to global change: 167-188. Academic Press, New York, New York, USA.

CHÁVEZ FP (1996) Forcing and biological impact of onset of the 1992 El Niño in central California. Geophysical Research Letters 23: 265-268.

CHÁVEZ FP, J RYAN, SE LLUCH-COTA \& MC NIQUEN (2003) From anchovies to sardines and back: multidecadal change in the Pacific ocean. Science 299: 217-221.

CHELTON DB (1981) Interannual variability of the California current: physical factors. California Cooperative Oceanic Fisheries Investigations Reports 22: 130-148.

CHELTON DB (1982) Seasonal variability of alongshore geostrophic velocity off central California. Journal of Geophysical Research 89: 3473-3486.

CHELTON DB \& RE DAVIS (1982) Monthly mean sea level variability along the west coast of North America. Journal of Physical Oceanography 12: 757-784.

CHELTON DB, PA BERNAL \& JA MCGOWAN (1982) Large-scale interannual physical and biological interaction in the California current. Journal of Marine Research 40: 1095-1125.

COHEN JE, F BRIAND \& CM NEWMAN (eds) (1990) Community food webs: data and theory. SpringerVerlag, Berlin, Germany. 308 pp.

CONNOLLY SR \& J ROUGHGARDEN (1998) A latitudinal gradient in northeast Pacific intertidal community structure: evidence for an oceanographically based synthesis of marine community theory. American Naturalist 151: 311-326.

CONNOLLY SR, BA MENGE \& J ROUGHGARDEN (2001) A latitudinal gradient in recruitment of intertidal invertebrates in the northeast Pacific ocean. Ecology 82: 1799-1813.

CUBIT JD (1984) Herbivory and the seasonal abundance of algae on a high intertidal rocky shore. Ecology 65: 1904-1917.

CURRIE RG (1991) Deterministic signals in tree-rings from Tasmania, New Zealand, and South Africa. Annals Geophysicae 9: 71-81.

CURRIE RG (1992) Deterministic signals in tree-rings from Europe. Annals Geophysicae 10: 241-253.

CURRIE RG (1993) Luni-solar 18-6- and solar cycle 1011-year signals in USA air temperature records. International Journal of Climatology 13: 31-50.

DAHLHOFF EP \& BA MENGE (1996) Influence of phytoplankton concentration and wave exposure on the ecophysiology of Mytilus californianus. Marine Ecology Progress Series 144: 97-107.

DAVIS GE, PL HAAKER \& DV RICHARDS (1996) Status and trends of white abalone at the California Channel Islands. Transactions of the American Fisheries Society 125: 42-48.

DAYTON PK (1971) Competition, disturbance, and community organization: The provision and subsequent utilization of space in a rocky intertidal community. Ecological Monographs 41: 351-389.

DAYTON PK (1985) The structure and regulation of some South American kelp communities. Ecological Monographs 55: 447-468.

DAYTON PK \& MJ TEGNER (1984) Catastrophic storms, El Niño, and patch stability in a southern California kelp community. Science 224: 283-285.
DAYTON PK \& MJ TEGNER (1990) Bottoms beneath troubled waters: benthic impacts of the 1982-1984 El Niño in the temperate zone. In: Glynn PW (ed) Global ecological consequences of the 1982-1983 El Niño-Southern Oscillation (1989): 433-472. Elsevier, Amsterdam, The Netherlands.

DAYTON PK, MJ TEGNER, PE PARNELL \& PB EDWARDS (1992) Temporal and spatial patterns of disturbance and recovery in a kelp forest community. Ecological Monographs 62: 421-445.

DAYTON PK, MJ TEGNER, PB EDWARDS \& KL RISER (1998) Sliding baselines, ghosts, and reduced expectations in kelp forest communities. Ecological Applications 82: 309-322.

DAYTON PK, MJ TEGNER, PB EDWARDS \& KL RISER (1999) Temporal and spatial scales of kelp demography: The role of oceanographic climate. Ecology 69: 219-250.

DENBO DW \& JS ALLEN (1987) Large-scale response to atmospheric forcing of shelf currents and coastal sea level off the west coast of North America: MayJuly, 1981-1982. Journal of Geophysical Research 92: $1757-1782$

DENNY MW \& RT PAINE (1998) Celestial mechanics, sea level changes, and intertidal ecology. Biological Bulletin 194: 108-115.

DOROFF AM, JA ESTES, MT TINKER, DM BURN \& TJ EVANS (2003) Sea otter population declines in the Aleutian archipelago. Journal of Mammalogy 84: 55-64.

DUGGINS D (1980) Kelp beds and sea otters: an experimental approach. Ecology 61: 447-453.

DUGGINS D, CA SIMENSTAD \& JA ESTES (1989) Magnification of secondary production by kelp detritus in coastal marine ecosystems. Science 245: 170-173.

DURÁN LR, JC CASTILLA \& D OLIVA (1987) Intensity of human predation on rocky shores at Las Cruces in central Chile. Environmental Conservation 14 143-149.

DURÁN R \& JC CASTILLA (1989) Variation and persistence of the middle rocky intertidal community, of central Chile, with and without human harvesting. Marine Biology 103: 555-562.

EBELING AW, DR LAUR \& RJ ROWLEY (1985) Severe storm disturbances and reversal of community structure in a southern California kelp forest. Marine Biology 84: 287-294.

EBERT TA \& MP RUSSELL (1988) Latitudinal variation in size structure of the west coast purple sea urchin: A correlation with headlands. Limnology and Oceanography 33: 286-294.

EMERY WJ \& K HAMILTON (1985) Atmospheric forcing of interannual variability in the northeast Pacific ocean connections with El-Niño. Journal of Geophysical Research-Oceans 90: 857-868.

ENFIELD D \& JS ALLEN (1980) On the structure and dynamics of monthly mean sea level anomalies along the Pacific coast of North and South America. Journal of Physical Oceanography 107: 5757-5787.

ENFIELD D, M CORNEJO-RODRÍGUEZ, RL SMITH \& PA NEWBERGER (1987) The equatorial source of propagating variability along the Peru coast during the 1982-1983 El Niño. Journal of Geophysical Research 92: 14335-14346.

ENFIELD DB \& AM MESTAS-NÚNEZ (1999) Multiscale variabilities in global sea surface temperatures and their relationships with tropospheric climate patterns. Journal of Climate 12: 2719-2733.

ESTES JA \& JF PALMISANO (1974) Sea otters: their role in structuring nearshore communities. Science 185 1058-1060. 
ESTES JA \& D DUGGINS (1995) Sea otters and kelp forests in Alaska: generality and variation in a community ecological paradigm. Ecological Monographs 65: 75-100.

ESTES JA, NS SMITH \& JF PALMISANO (1978) Sea otter predation and community organization in western Aleutian Islands, Alaska. Ecology 59: 822833.

ESTES JA, MT TINKER, TM WILLIAMS \& DF DOAK (1998) Killer whale predation on sea otters: linking oceanic and nearshore ecosystems. Science 282: 473-476.

FARRELL TM, D BRACHER \& J ROUGHGARDEN (1991) Cross-shelf transport causes recruitment to intertidal populations in central California. Limnology and Oceanography 36: 279-288.

FERNÁNDEZ M, E JARAMILLO, P MARQUET C MORENO, S NAVARRETE, P OJEDA, C VALDOVINOS \& J VÁSQUEZ (2000) Diversity, dynamics and biogeography of Chilean benthic nearshore ecosystems: an overview and guidelines for conservation. Revista Chilena de Historia Natural 73: 797-830.

FIEDLER PC (1984) Satellite observations of the 19821983 El Niño along the US Pacific coast. Science 224: 1251-1254.

FONSECA T (1985) Efectos físicos del fenómeno El Niño 1982-1983 en la costa chilena. Investigación Pesquera (Chile) 32: 61-68.

FONSECA T (1989) An overview of the poleward undercurrent and upwelling along the Chilean coast. In: Neshyba SJ, CNK Mooers, RL Smith \& RT Barber (eds) Poleward flows along eastern ocean boundaries: 203-228. Springer-Verlag, New York, New York, USA.

FONSECA T \& M FARÍAS (1987) Estudio del proceso de surgencia en la costa chilena utilizando percepción remota. Investigación Pesquera (Chile) 34: 33-46.

FOOD AND AGRICULTURE ORGANIZATION OF THE UNITED NATIONS (1993) FAO Yearbook of Fishery Statistics, 1991: 395. Food and Agricultural Organization of the United Nations, Rome, Italy.

FOOD AND AGRICULTURE ORGANIZATION OF THE UNITED NATIONS (1996) FAO Yearbook of Fishery Statistics, 1996: 179. Food and Agricultural Organization of the United Nations, Rome, Italy.

FRANCIS RC \& SR HARE (1994) Decadal-scale regime shifts in the large marine ecosystems of the northeast Pacific: a case for historical science. Fisheries Oceanography 3: 279-291.

FRANK PW (1982) Effects of winter feeding on limpets by black oystercatchers, Haematopus bachmani. Ecology 63: 1352-1362.

GARGETT AE (1997) The optimal stability "window": a mechanism underlying decadal fluctuations in North Pacific salmon stocks. Fisheries Oceanography 6: 109-117.

GILL AE \& AJ CLARKE (1974) Wind-induced upwelling, coastal currents and sea-level changes. Deep-Sea Research 21: 325-345.

GODOY C \& CA MORENO (1989) Indirect effects of human exclusion from the rocky intertidal in Southern Chile: a case of cross-linkage between herbivores. Oikos 54: 101-106.

GRAHAM MH (1996) Effect of high irradiance of recruitment of the giant kelp Macrocystis (Phaeophyta) in shallow water. Journal of Phycology 32: 903-906.

GRAHAM NE (1994) Decadal scale variability in the 1970's and 1980's: observations and model results. Climate Dynamics 10: 60-70.
GUNNILL FC (1985) Population fluctuations of seven macroalgae in southern California during 19811983 including effects of severe storms and an El Niño. Journal of Experimental Marine Biology and Ecology 85: 149-164.

HAHN T \& M DENNY (1989) Tenacity mediated selective predation by oystercatchers on intertidal limpets and its role in maintaining habitat partitioning by Collisella scabra and Lottia digitalis. Marine Ecology Progress Series 53: 1-10.

HARROLD C \& DC REED (1985) Food availability, sea urchin grazing, and kelp forest community structure. Ecology 66: 1160-1169.

HARVELL CD, K KIM, JM BURKHOLDER, RR COLWELL, PR EPSTEIN, DJ GRIMES, EE HOFMANN, EK LIPP, AD OSTERHAUS, RM OVERSTREET, JW PORTER, GW SMITH \& GR VASTA (1999) Emerging marine diseases-climate links and anthropogenic factors. Science 285: 15051510 .

HAYWARD TL, SL CUMMINGS, DR CAYAN, FP CHAVEZ, RJ LYNN, AW MANTYLA, PP NIILER, FB SCHWING, RR VEIT \& EL VENRICK (1996) The state of the California Current in 1995-1996: continuing declines in macrozooplankton biomass during a period of nearly normal circulation. California Cooperative Oceanic Fisheries Investigations Reports 37: 22-37.

HELMUTH B, CDG HARLEY, PM HALPIN, M O'DONNELL, GE HOFMANN \& CA BLANCHETTE (2002) Climate change and latitudinal patterns of intertidal thermal stress. Science 298: 1015-1017.

HICKEY BM (1979) The California Current system: hypotheses and facts. Progress in Oceanography 8: 191-279.

HICKEY BM (1989) Patterns and processes of circulation over the continental shelf off Washington. In: Landry MR \& BM Hickey (eds) Coastal oceanography of Washington and Oregon: 441-451. Elsevier, New York, New York, USA.

HICKEY BM (1998) Coastal oceanography of western North America from the tip of Baja California to Vancouver Island. In: Robinson AR \& KH Brink (eds) The Sea: 345-394. John Wiley and Sons, Inc., New York, New York, USA.

HOBDAY AJ \& MJ TEGNER (2002) The warm and the cold: influence of temperature and fishing on local population dynamics of red abalone. California Cooperative Oceanic Fisheries Investigations Reports 43: 74-96.

HOFFMANN A \& B SANTELICES (1997) Flora marina de Chile central. Ediciones Universidad Católica de Chile, Santiago, Chile. 434 pp.

HOLLOWED AB \& WS WOOSTER (1992) Variability of winter ocean conditions and strong year classes of northeast Pacific groundfish. ICES Marine Science Symposia 195: 433-444.

HUYER A, M KNOLL, T PALUSZKIEWICZ \& RL SMITH (1991) The Peru undercurrent: a study in variability. Deep-Sea Research 38: S247-S271.

JARA HF \& CA MORENO (1984) Herbivory and structure in a midlittoral rocky community: a case in southern Chile. Ecology 65: 28-38.

KATO S \& SC SCHROETER (1985) Biology of the red sea urchin, Strongylocentrotus franciscanus, and its fishery in California. Marine Fisheries Review 47: 1-20.

KNUDSEN T \& N VOGEL (1997) Sea creatures in tide pools occupy a precarious perch. In: San Francisco Sunday Examiner and Chronicle: B-6, San Francisco, USA. 
LAUR DR, AW EBELING \& DA COON (1988) Effects of sea otter foraging on subtidal reef communities off central California. In: Blaricom GRV \& JA Estes (eds) The community ecology of sea otters: 151167. Springer-Verlag, Berlin, Germany.

LIMBERGER D (1990) El Niño's effect on South American pinniped species. In: Glynn PW (ed) Global ecological consequences of the 1982-1983 El Niño Southern Oscillation: 417-430. Elsevier, Amsterdam, The Netherlands.

LODER JW \& C GARRETT (1978) The 18.6 year cycle of sea surface temperature in shallow seas due to variation in tidal mixing. Journal of Geophysical Research 83: 1967-1970.

LOHSE DP (1993) The effects of substratum type on the population dynamics of three common intertidal animals. Journal of Experimental Marine Biology and Ecology 173: 133-154.

LUBCHENCO J, SA NAVARETTE, BN TISSOT \& JC CASTILLA (1993) Possible ecological responses to global climate change: nearshore benthic biota of northeastern Pacific coastal ecosystems. In: Mooney HA, ER Fuentes \& BI Kronberg (eds) Earth system responses to global change: contrasts between North and South America: 147-166. Academic Press, New York, New York, USA.

LUKAS R (1986) The termination of the equatorial undercurrent in the eastern Pacific. Progress in Oceanography 16: 63-90.

LYNN RJ \& JJ SIMPSON (1987) The California current system: the seasonal variability of its physical characteristics. Journal of Geophysical Research 92: 2515-2534.

MAKSIMOV IV \& NP SMIRNOV (1967) A contribution to the study of the causes of long period variations in the activity of the Gulf stream. Oceanology 5: 15-24.

MANRÍQUEZ PH \& JC CASTILLA (2001) Significance of marine protected areas in central Chile as seeding grounds for the gastropod Concholepas concholepas. Marine Ecology Progress Series 215: 201-211.

MANTUA NJ, SR HARE, Y ZHANG, JM WALLACE \& RC FRANCIS (1997) A Pacific interdecadal climate oscillation with impacts on salmon production. Bulletin of the American Meteorological Society 78: 1069-1079.

MAURER D \& H NGUYEN (1997) The relationship between on ocean outfall and sediment properties from the San Pedro shelf, California. Bulletin Southern California Academy of Sciences 96: 22-33.

MCCALL AD (1996) Patterns of low-frequency variability in fish populations of the California current. California Cooperative Oceanic Fisheries Investigations Reports 37: 100-110.

MCGOWAN JA, DB CHELTON \& A CONVERSI (1996) Plankton patterns, climate, and change in the California current. California Cooperative Oceanic Fisheries Investigations Reports 37: 45-69.

MCGOWAN JA, DR CAYAN \& LM DORMAN (1998) Climate-ocean variability and ecosystem response in the northeast Pacific. Science 281: 210-217.

MCLEAN JH (1962) Sublittoral ecology of kelp beds of the open coast near Carmel. Biological Bulletin 122: $213-219$.

MCNALLEY GI (1981) Satellite-tracked drift buoy observations of the surface flow in the mid-latitude North Pacific. Journal of Geophysical Research 86: 8022-2030

MENGE BA (1992) Community regulation: Under what conditions are bottom up factors important in rocky shores? Ecology 73: 755-765.
MENGE BA, B DALEY \& PA WHEELER (1996) Control of interaction strength in marine benthic communities. In: Polis GA \& R Winemuller (eds) Food webs: integration of pattern and process: 258274. Chapman and Hall, New York, New York, USA.

MENGE BA, BA DALEY, PA WHEELER \& PT STRUB (1997a) Rocky intertidal oceanography: an association between community structure and nearshore phytoplankton concentration. Limnology and Oceanography 42: 57-66.

MENGE BA, EG BERLOW, CA BLANCHETTE, SA NAVARRETE \& SB YAMADA (1994) The keystone species concept: variation in interaction strength in a rocky intertidal habitat. Ecological Monographs 64: 249-286.

MENGE BA, BA DALEY, PA WHEELER, E DAHLHOFF, E SANFORD \& PT STRUB (1997b) Benthic-pelagic links and rocky intertidal communities: bottom-up effects on top-down control? Proceedings of the National Academy of Science of the United States of America 94: 1453014535.

MENGE BA, BA DALEY, J LUBCHENCO, E SANFORD, E DAHLHOFF, PM HALPIN, G HUDSON \& JL BURNAFORD (1999) Top-down and bottom-up regulation of New Zealand rocky intertidal communities. Ecological Monographs 69: 297-330.

MILLER AJ (1996) Recent advances in California current modeling: decadal and interannual thermocline variations. California Cooperative Oceanic Fisheries Investigations Reports 37: 69-79.

MILLER AJ, DR CAYAN, TP BARNETT, NE GRAHAM \& JM OBERHUBER (1994) Interdecadal variability of the Pacific Ocean: model response to observed heat flux and wind stress anomalies. Climate Dynamics 9: 287-302.

MOORE JD, CA FINLEY, TT ROBBINS \& CS FRIEDMAN (2002) Withering syndrome and restoration of southern California abalone populations. California Cooperative Oceanic Fisheries Investigations Reports 43: 112-117.

MORENO CA (1986) Un resumen de las consecuencias ecológicas de la exclusión del hombre en la zona intermareal de Mehuin -Chile. Estudios Oceanológicos (Chile) 5: 59-66.

MORENO CA \& JP SUTHERLAND (1982) Physical and biological processes in a Macrocystis pyrifera community near Valdivia, Chile. Oecologia 55: 1-6.

MORENO CA \& E JARAMILLO (1983) The role of grazers in the zonation of intertidal macroalgae of the Chilean coast. Oikos 41: 73-76.

MORENO CA, KM LUNECKE \& MI LÓPEZ (1986) The response of an intertidal Concholepas concholepas (Gastropoda) population to protection from man in southern Chile and the effects on benthic sessile assemblages. Oikos 46: 359-364.

MORENO CA, G ASCENSIO, WE DUARTE \& V MARÍN (1998) Settlement on the muricid Concolepas concholepas and its relationship with El Niño and coastal upwellings in Chile. Marine Ecology Progress Series 167: 171-175.

MYSAK LA (1986) El Niño, interannual variability and fisheries in the northeast Pacific Ocean. Canadian Journal of Fisheries and Aquatic Science 43: 464497.

NATIONAL RESEARCH COUNCIL COPAMOPNAS (1996) Upstream: salmon and society in the Pacific Northwest. National Academy of Science Press, Washington, District of Columbia, USA. 452 pp. 
NAVARRETE SA \& BA MENGE (1996) Keystone predation and interaction strength: interactive effects of predators on their main prey. Ecological Monographs 66: 409-429.

NAVARRETE SA \& JC CASTILLA (2003) Experimental determination of predation intensity in an intertidal predator guild: dominant versus subordinate prey. Oikos 100: 251-262.

NAVARRETE SA, B BROITMAN, EA WIETERS, GR FINKE, RM VENEGAS \& A SOTOMAYOR (2002) Recruitment of intertidal invertebrates in the southeast Pacific: interannual variability and the 1997-1998 El Niño. Limnology and Oceanography 47: 791-802.

NESHYBA SJ, CNK MOOERS, RL SMITH \& RT BARBER (eds) (1989). Poleward flows along eastern ocean boundaries. Springer-Verlag, New York, New York, USA. 374 pp.

NIELSEN KJ (2001) Bottom-up and top-down forces in tide pools: test of a food chain model in an intertidal community. Ecological Monographs 71: 187-217.

NIELSEN KJ (2003) Nutrient loading and consumers: agents of change in open-coast macrophyte assemblages. Proceedings of the National Academy of Sciences of the United States of America 100: 7660-7665.

NORTH W (1983) Separating the effects of temperature and nutrients. Bascom W (ed). The effects of waste disposal on kelp communities: 243-255. California Sea Grant College Program, California, USA.

NORTH WJ (1971) Introduction and background. In: North WJ (ed) The biology of giant kelp beds (Macrocystis) in California: 1-97. J Cramer, Lehre, USA.

OSHURKOV VV, AG BAZHIN, VI LUKIN \& VF SEVOSTYANOV (1988) Sea otter predation and the benthic community structure of the Commander Islands. Biologia Morya (Vladivostok) 6: 50-60.

PACIFIC FISHERIES MANAGEMENT COUNCIL (2001) Review of the 2000 ocean salmon fisheries. Pacific Fisheries Management Council, Portland, Oregon, USA. 267 pp.

PAINE RT (1966) Food web complexity and species diversity. American Naturalist 100: 65-76.

PAINE RT (1974) Intertidal community structure: experimental studies on the relationship between a dominant competitor and its principal predator. Oecologia 15: 93-120.

PAINE RT (1976) Size-limited predation: an observational and experimental approach with the MytilusPisaster interaction. Ecology 57: 858-873.

PAINE RT (1980) Food webs: linkage, interaction strength and community infrastructure. Journal of Animal Ecology 49: 667-685.

PAINE RT (1986) Benthic community-water column coupling during the 1982-1983 El Niño. Are community changes at high latitudes attributable to cause or coincidence? Limnology and Oceanography 31: 351-360.

PAINE RT \& AR PALMER (1978) Sicyases sanguineas: a unique trophic generalist from the Chilean intertidal zone. Copeia 1978: 75-81.

PAINE RT \& SA LEVIN (1981) Intertidal landscapes: disturbance and the dynamics of pattern. Ecological Monographs 51: 145-178.

PARES-SIERRA A \& JJ O'BRIEN (1989) The seasonal and interannual variability of the California current system: a numerical model. Journal of Geophysical Research 94: 3159-3180.

PARKER KS, TC ROYER \& RB DERISO (1995) High latitude climate forcing and tidal mixing by the 18.6 year lunar nodal cycle and low frequency recruitment trends in Pacific halibut (Hippoglossus stenolepis). In: Beamish RJ (ed) Climate change and northern fish populations: 447-459. Canadian Special Publications in Fisheries and Aquatic Sciences. NRC Press, Ottawa, Canada. 739 pp.

PARRISH RH (1997) Regime-scale fluctuations in the circulation of the North Pacific. In: Emmett RL \& $\mathrm{MH}$ Schiewe (eds) Estuarine and ocean survival of northeastern Pacific salmon: NMFS-NWFSC-29. $95104 \mathrm{pp}$.

PEARCY WG (1992) Ocean ecology of North Pacific salmonids. University of Washington Press, Seattle, Washington, USA. 179 pp.

PEARSE JS \& AH HINES (1987) Long term population dynamics of sea urchins in a central California kelp forest: rare recruitment and rapid decline. Marine Ecology Progress Series 39: 275-283.

PETERSON W (1998) Life cycle strategies of copepods in coastal upwelling zones. Journal of Marine Systems 15: 313-326.

PFISTER CA \& A BRADBURY (1996) Harvesting red sea urchins: recent effects and future predictions. Ecological Applications 6: 298-310.

PIERCE SD, RL SMITH, PM KOSRO, JA BARTH \& CD WILSON (2000) Continuity of the poleward undercurrent along the eastern boundary of the midlatitude north Pacific. Deep-Sea Research 47: 811829.

POLOVINA JJ, GT MITCHUM \& GT EVANS (1995) Decadal and basin-scale variation in mixed-layer depth and the impact on biological production in the central and North Pacific, 1960-1988. Deep-Sea Research 42: 1701-1706.

POULIN E, AT PALMA, G LEIVA, E HERNÁNDEZ, P MARTÍNEZ, SA NAVARRETE \& JC CASTILLA (2002a) Temporal and spatial variation in the distribution of epineustonic competent larvae of Concholepas concholepas along the central coast of Chile. Marine Ecology Progress Series 229: 95-104.

POULIN E, AT PALMA, G LEIVA, D NARVÁEZ, R PACHECO, SA NAVARRETE \& JC CASTILLA (2002b) Avoiding offshore transport of competent larvae during upwelling events: The case of the gastropod Concholepas concholepas in Central Chile. Limnology and Oceanography 47: 12481255.

PREISENDORFER RW (1988) Principal component analysis in meteorology and oceanography. Elsevier, New York, New York, USA. 425 pp.

RAY GC, BP HAYDEN, AJ BULGAR JR\& MG MCCORMICK-RAY (1992) Effects of global warming on the biodiversity of coastal marine zones. In: Peters RL \& TE Lovejoy (eds) Global warming and biodiversity: 91-104. Yale University Press, New Haven, Connecticut, USA.

ROBLES CD (1997) Changing recruitment in constant species assemblages: implications for predation theory in intertidal communities. Ecology 78: 14001414.

ROBLES CD \& J CUBIT (1981) Influence of biotic factors in an upper intertidal community: dipteran larvae grazing on algae. Ecology 62: 1536-1547.

RODRÍGUEZ SR (2003) Consumption of drift kelp by intertidal populations of the sea urchin Tetrapygus niger on the central Chilean coast: possible consequences at different ecological levels. Marine Ecology Progress Series 251: 141-151.

ROEMMICH D \& J MCGOWAN (1995) Climatic warming and the decline of zooplankton in the California current. Science 467: 1324-1326. 
ROGERS-BENNETT L, PL HAAKER, TO HUFF \& PK DAYTON (2002a) Estimating baseline abundances of abalone in California for restoration. California Cooperative Oceanic Fisheries Investigations Reports 43: 97-111.

ROGERS-BENNETT L, D BERGEN, P COLLIER, M ERICKSON, P KALVASS, C KONG, J O'BRIEN, K ODA, J O'LEARY, D ONO, K O'REILLY, D OSORIO, K WALTERS, R LEOS, V TAYLOR, D THOMAS, A VEJAR \& D SWEETNAM (2002b) Review of some California fisheries for 2001: market squid, sea urchin, dungeness crab, lobster, prawn, abalone, groundfish, swordfish and shark, coastal pelagic finfish, ocean salmon, nearshore live-fish, Pacific herring, white seabass, and kelp. California Cooperative Oceanic Fisheries Investigations Reports 43: 13-30.

ROUGHGARDEN J, S GAINES \& H POSSINGHAM (1988) Recruitment dynamics in complex life cyles. Science 241: 1397-1560.

ROUGHGARDEN J, JT PENNINGTON, D STONER, S ALEXANDER \& K MILLER (1991) Collisions of upwelling fronts with the intertidal zone: the cause of recruitment pulses in barnacle populations of central California. Acta Oecologica 12: 35-51.

ROYER TC (1993) High latitude oceanic variability associated with the 18.6-year nodal tide. Journal of Geophysical Research 98: 4639-4644.

SAGARIN RD, JP BARRY, SE GILMAN \& CH BAXTER (1999) Climate-related change in an intertidal community over short and long time scales. Ecological Monographs 69: 465-490.

SANFORD E (1999) Regulation of keystone predation by small changes in ocean temperature. Science 283: 2095-2097.

SANFORD E, MS ROTH, GC JOHNS, JP WARES \& GN SOMERO (2003) Local selection and latitudinal variation in a marine predator-prey interaction. Science 300: 1135-1137.

SANTELICES B \& FP OJEDA (1984) Population dynamics of a coastal forest of Macrocystis pyrifera in Puerto Toro, Isla Navarino, southern Chile. Marine Ecology Progress Series 14: 175-183.

SANTELICES B \& R NORAMBUENA (1987) A harvesting strategy for Iridaea laminarioides in central Chile. In: Ragan MA \& CJ Bird (ed) Hydrobiologia, Twelfth International Seaweed Symposium: 329-333. Dr. W. Junk Publishers, Dordrecht, The Netherlands.

SANTELICES B, S MONTALVA \& P OLIGER (1981) Competitive algal community organization in exposed intertidal habitats from central Chile. Marine Ecology Progress Series 6: 267-276.

SANTELICES B, JC CASTILLA, J CANCINO \& P SCHMIEDE (1980) Comparative ecology of Lessonia nigrescens and Durvillaea antarctica (Phaeophyta) in central Chile. Marine Biology 59: 119-132.

SCHIEL DR \& MS FOSTER (1986) The structure of subtidal algal stands in temperate waters. Oceanography and Marine Biology Annual Review 24: 265-307

SCHROETER SC, TA DEAN, K THIES \& JD DIXON (1995) Effects of shading by adults on the growth of blade stage Macrocystis pyrifera (Phaeophyta) during and after the 1982-1984 El Nino. Journal of Phycology 31: 697-702.

SCHWARTZLOSE RA, J ALHEIT, T BAUMGARTNER, R CLOETE, RJM CRAWFORD, WJ FLETCHER, Y GREEN-RUIZ, E HAGEN, T KAWASAKI, D LLUCH-BELDA, SE LLUCH-COTA, AD MACCALL, Y MATSUURA, MO NEVIREZ-
MARTINEZ, RH PARRISH, C ROY, R SERRA, KV SHUST, NM WARD \& JZ ZUZUNAGA (1999) Worldwide large-scale fluctuations of sardine and anchovy populations. South African Journal of Marine Science 21: 289-347.

SCHWING FB \& R MENDELSSOHN (1997) Increased coastal upwelling in the California current system. Journal of Geophysical Research 120: 3421-3438.

SHAFFER G, O PIZARRO, L DJURFELDT, S SALINAS \& J RUTLLANT (1997) Circulation and low-frequency variability near the Chilean coast: remotely forced fluctuations during the 1991-92 El Niño. Journal of Physical Oceanography 27: 217-235.

SHEPHERD SA, JR TURRUBIATES-MORALES \& K HALL (1998) Decline of the abalone fishery at La Natividad, Mexico: overfishing or climate change? Journal of Shellfish Research 17(3): 839-846.

SILVA N \& S NESHYBA (1979) On the southernmost extension of the Peru-Chile undercurrent. Deep-Sea Research 26: 1387-1393.

SIMENSTAD CA, JA ESTES \& KW KENYON (1978) Aleuts, sea otters, and alternate stable-state communities. Science 200: 403-411.

SIMPSON JJ (1984) A simple model of the 1982-1983 California "El Niño". Geophysical Research Letters 11: 237-240.

SMITH RL (1992) Modern ocean upwelling. In: Summerhayes CP, WL Prell \& KC Emeis (eds) Upwelling systems: evolution since the early Miocene: 9-28. Geological Society, London, Special Publication, London, United Kingdom

SOTO R (1985) Efectos del fenómeno El Niño. 1982-1983 E1 Niño ecosistemas de la primera región. Investigación Pesquera (Chile) 32: 199-206.

STRUB PT \& C JAMES (1995) The large-scale summer circulation of the California current. Geophysical Research Letters 22: 207-210.

STRUB PT \& C JAMES (2000) Altimeter-derived variability of surface velocities in the California current system: seasonal circulation and eddy statistics. Deep-Sea Research 47: 831-870.

STRUB PT \& C JAMES (2002a) Altimeter-derived surface circulation in the large-scale northeast Pacific gyres: seasonal variability. Progress in Oceanography 53: 163-183

STRUB PT \& C JAMES (2002b) Altimeter-derived surface circulation in the large-scale northeast Pacific gyres: 1997-1998 El Niño anomalies. Progress in Oceanography 53: 185-214.

STRUB PT, JM MESÍAS \& C JAMES (1995) Satellite observations of the Peru-Chile countercurrent. Geophysical Research Letters 22: 211-214.

STRUB PT, C JAMES, AC THOMAS \& MR ABBOTT (1990) Seasonal and nonseasonal variability of satellite-derived surface pigment concentration in the California current. Journal of Geophysical Research 95: 11501-11530.

STRUB PT, PM KOSRO, A HUYER \& CTZ COLLABORATORS (1991) The nature of the cold filaments in the California current system. Journal of Geophysical Research 96: 14743-14768.

STRUB PT, JM MESÍAS, V MONTECINO, J RUTLLANT \& S SALINAS (1998) Coastal ocean circulation off western South America. In: Robinson AR \& KH Brink (eds) The Sea: 273-314. John Wiley \& Sons, Inc, New York, New York, USA.

STULL JK (1995) Two decades of marine biological monitoring, Palos Verdes, California, 1972 to 1992. Bulletin Southern California Academy of Sciences 94: 21-45. 
TEGNER MJ \& PK DAYTON (1981) Population structure, recruitment and mortality of two sea urchins (Strongylocentrotus franciscanus and $S$. purpuratus) in a kelp forest. Marine Ecology Progress Series 5: 255-268.

TEGNER MJ \& PK DAYTON (1987) El Niño effects on southern California kelp forest communities. Advances in Ecological Research 17: 243-279.

TEGNER MJ, PK DAYTON, PB EDWARDS\& KL RISER (1995) Sea urchin cavitation of giant kelp (Macrocystis pyrifera C. Agardh) holdfasts and its effects on kelp mortality across a large California forest. Journal of Experimental Marine Biology and Ecology 191: 83-99.

THOMAS AC, F HUANG, PT STRUB \& C JAMES (1994) A comparison of the seasonal and interannual variability of phytoplankton pigment concentrations in the Peru and California current systems. Journal of Geophysical Research 99: 7355-7370.

TOMICIC JJ (1985) Efectos del fenómeno El Niño 19821983 El Niño las comunidades litorales de la Península de Mejillones. Investigación Pesquera (Chile) 32: 209-213.

TSUCHIYA M (1985) The subthermocline phosphate distribution and circulation in the far eastern equatorial Pacific Ocean. Deep-Sea Research 32: 299-313.

UNITED STATES DEPARTMENT OF COMMERCE NATIONAL MARINE FISHERIES SERVICE (1998) Endangered and threatened species; threatened status for the Oregon coast evolutionary significant unit of coho salmon. United States Federal Register 63(153): 42587-42591.

UNITED STATES DEPARTMENT OF COMMERCE NATIONAL OCEANIC AND ATMOSPHERIC ADMINISTRATION (2001) Endangered and threatened species; endangered status for white abalone. United States Federal Register 66(103): 29046-29055.

UNITED STATES DEPARTMENT OF THE INTERIOR FISH AND WILDLIFE SERVICE (1995) Endangered and threatened species; proposed threatened status for three contiguous ESUs of coho salmon ranging from Oregon through Central California. United States Federal Register 62: 38011-38030.

UNITED STATES DEPARTMENT OF THE INTERIOR FISH AND WILDLIFE SERVICE (1996) Endangered and threatened wildlife and plants; listing of the central California coast coho salmon as threatened in California. United States Federal Register 661: 59028-59029.

UNITED STATES DEPARTMENT OF THE INTERIOR FISH AND WILDLIFE SERVICE (1997) Endangered and threatened wildlife and plants; threatened status for the southern Oregon/northern
California coast evolutionary significant unit of coho salmon. United States Federal Register 62: 33038-33039.

UNITED STATES GLOBAL OCEAN ECOSYSTEMS DYNAMICS (GLOBEC) (1996) United State GLOBEC northeast Pacific implementation plan. United State GLOBEC Scientific Steering Committee Coordinating Office, Berkeley, California, USA. 60 pp.

VÁSQUEZ JA \& AH BUSCHMANN (1997) Herbivorekelp interactions in Chilean subtidal communities: a review. Revista Chilena de Historia Natural 70: 4152 .

VEIT RR, P PYLE \& JA MCGOWAN (1996) Ocean warming and long term change in pelagic bird abundance within the California current system. Marine Ecology Progress Series 139: 11-18.

VENRICK IL, JA MCGOWAN, DR CAYAN \& TL HAYWARD (1987) Climate and chlorophyll a: long-term trends in the central North Pacific Ocean. Science 238: 70-72.

WARE DM (1995) A century and a half of change in the climate of the Northeast Pacific. Fisheries Oceanography 4: 267-277.

WATANABE JM \& C HARROLD (1991) Destructive grazing by sea urchins Strongylocentrotus spp. in a central California kelp forest potential roles of recruitment, depth, and predation. Marine Ecology Progress Series 71: 125-141.

WICKETT WP (1967) Ekman tanspot and zooplankton concentration in the North Pacific. Journal of the Fisheries Research Board Canada 24: 581-594.

WIETERS EA, DM KAPLAN, SA NAVARRETE, A SOTOMAYOR, J LARGIER, KJ NIELSEN \& F VÉLIZ (2003) Alongshore and temporal variability in chlorophyll a concentration in Chilean nearshore waters. Marine Ecology Progress Series 249: 93-105.

WING SR, JL LARGIER, LW BOTSFORD \& JF QUINN (1995) Settlement and transport of benthic invertebrates in an intermittent upwelling region. Limnology and Oceanography 40: 316-329.

WOOSTER WS \& DL FLUHARTY (1985) El Niño North: Niño effects in the eastern subarctic Pacific Ocean. University of Washington Press, Seattle, Washington, USA. 312 pp.

WOOTTON JT (1997) Estimates and tests of per capita interaction strength: diet, abundance, and impact of intertidally foraging birds. Ecological Monographs 67: 45-64.

WOOTTON JT, ME POWER, RT PAINE \& CA PFISTER (1996) Effects of productivity, consumers, competitors, and El Niño events on food chain patterns in a rocky intertidal community. Proceedings of the National Academy of Sciences of the United States of America 93: 13855-13858. 